\title{
PSYCHOSES ASSOCIATED WITH INFLUENZA
}

\section{SPECIFIC DATA. AN EXPOSITORY ANALYSIS *}

KARL A. MENNINGER, M.S., M.D.

Assistant in Neuropathology, Harvard Medical School ; Assistant in Neurology, Tufts Medical School

TOPEKA, KANSAS

Psychic disturbances associated with influenza are first mentioned in the literature in connection with an epidemic of 1385 in Germany. ${ }^{1}$ The "deliria" of the epidemic of 1387 are mentioned in accounts ${ }^{2}$ by Valescus de Taranta and Gassar. The "vexatious deliria" of the epidemic of 1510 are mentioned by Mezèray. ${ }^{3}$ In "Annals of Influenza," 4 published in 1852, Riverius ${ }^{5}$ is quoted regarding the epidemic of 1580 thus: "It began with a fever and cough, then followed again a pain of the head and loins, then the fever intermitted a few days and returned with fresh vigor. Some had no rest, but the heat increasing they died ; as some did of a phrenzy (!) and others of a consumption." Henisch the First spoke of the extreme prostration, "somnolent states, lipothymias, and other disquieting incidents" of this same epidemic. Quoted by Espagnol, ${ }^{8}$ Ozanam ${ }^{7}$ recounts the occurrence of "such grave symptoms as convulsive movements and somnolence" after the disease in the epidemic of 1691. Schweig ${ }^{8}$ described an epidemic in 1737 with psychic disorders similar to those he found mentioned in connection "Maladie du Sommeil," because of the somnolent and stuporous states following it (1718).

* Contribution I was published in J. A. M. A. 72:235 (Jan. 25) 1919.

*A contribution from the Psychopathic Department, Boston State Hospital series of 1919.

1. Schnurrer: Chron. der Seuchen, t. I, par. 352; 1385.

2. Kusnekow, A. C., and Hermann, F. L.: Influenza, Eine geschichtliche und klinische Studie, Wien., 1890.

3. Mezèray is quoted by Leledy but no reference could be found except to Sennert, de Abditis Rerum causis, lib. II, cap. 12, 510, q. v.

4. Annals of Influenza in Great Britain from 1510 to 1837; Thompson, London, 1852.

5. Riverius: Opera omni medica, Lugd. 1669, p. 585.

with the epidemic of 1580 . Camerarius ${ }^{9}$ gave influenza the name

6. Espagnol, Jean: Contribution a l'etude des rapports de la grippe et du systeme nerveux, Toulouse, 1895.

7. Ozanam: Histoire médicale des maladies épidémiques contagieuses et épizootiques, Paris, 1835.

8. Schweig: Die Influenza, Berlin, 1836.

9. Camerarius: Quoted by Espagnol, without reference. 
But despite these and other mentions of the concomitant deliria and numerous neurological manifestations, it remained for an American to signalize the association of "symptoms of madness" and "loss of reason" with influenza. This was Benjamin Rush of Philadelphia, in "An Account of the Influenza as it Appeared in Philadelphia, 1789, 1790 and 1791." 10 Thereafter there were sporadic reports, for example, by Bonnet in 1837 "of an individual in whom the grippe provoked a furious mania"; by Pétrequin, who spoke of "patients tormented by sad ideas," and of "four or five suicides . . . in the hospitals of Paris" in the epidemic of 1837 ; by Chrichton-Brown in 1874, of "acute dementia following the grippe." 11, 12,13

The epidemic of 1890 was evidently followed by many cases of mental disease, and the increased interest in psychiatry at this period brought forth a shower of literary progeny. Innumerable articles and reports appeared then and thereafter relative to the association of influenza with mental and nervous disease. Of the hundreds of names which are available in any complete bibliography, a few stand out as of preeminent importance and are still frequently quoted. Thus Kraepelin ${ }^{14}$ and Bonhoeffer ${ }^{15}$ are known because of their later prestige ; Leichtenstern ${ }^{16}$ for his comprehensive study of influenza as a whole; $\mathrm{Kirn}^{17}$ because of his numerous able contributions; Ladame, ${ }^{18}$ Bidon, ${ }^{19}$ and others of the French school because of the different viewpoint represented by them; and Leledy ${ }^{20}$ and Bossers ${ }^{21}$ for thorough historical and bibliographical records of the association of influenza and

10. Rush: An Account of Influenza as It Appeared in Philadelphia, 1789 , 1790 and 1791. Inquiries and Observations, Philadelphia, 1805; p. 353.

11. Bonnet: J. de méd. de Bordeaux, 2nd series, Part 5, p. 175, 1837.

12. Pétrequin: Gaz. méd. de Par. 51:801 (Dec. 23) 1837.

13. Chrichton-Brown, J.: West Riding Lunatic Asylum Medical Reports 55:269, 1874.

14. Kraepelin, E. : Ueber den Einfluss acuter Krankheiten auf die Enstehung von Geisteskrankheiten, Arch. f. Psychiat. 11: 1881, and 12: 1882. Also, Ueber Psychosen nach Influenza in Dorpat, Deutsch. med. Wchnschr. 11: (March 13) 1890.

15. Bonhoeffer: In Aschaffenburg's Handbuch (Leipzig and Vienna), 1912.

16. Leichtenstern, O.: In Nothnagel's Encyclopedia. "Influenza." English translation by Stengel, 1905, Philadelphia, W. B. Saunders Co.

17. Kirn: Ueber Influenza Psychosen, Munchen. med. Wchnschr. 37:299301, 1890. Die nervoesen und psychischen Stoerungen der Influenza, Samml. klin. Vortr., n. F. 23: Leipzig, 1891; Die Psychosen der Influenza, Allg. Ztschr. f. Psychiat. 48:1-15, 1891-1892.

18. Ladame: Annal. méd.-psychol. 13:20, 1896.

19. Bidon: Revue de Medécine, 1890.

20. Leledy, A.: Lagrippe et alienation mentale, 4, Paris, 1891.

21. Bossers, A. J.: Die Geschichte der Influenza und ihre nervoesen und psychischen Nachkrankheiten, Leiden, 1894. 
psychosis. (The historical summary of the first paragraph of this paper is based in large part on these accounts.) In addition there were a great number of current literature accounts - about 220 authors are listed in the Surgeon-General's Index Catalog, 1902 volume. Books on the subject were issued in German by Ahrens, Borchardt, Bossers, Brachmann, Eberlings, Hirschfeld, Jutroinski, Klemm, Lochner, Mispelbaum, Mucha, Wescher and Weynerowski; in French by Auguin, Biet, Brionne, De Groote, Diemer, Espagnol, Lehmann, Le Joubieux, Leledy, Lestra, Ulliel, Trastour, and Virey ; in Danish by Fehr, and in Italian by Rossi. I know of no books in the English language.

All of these accounts have a certain intrinsic interest, but many of them are of dubious value to the present day psychiatrist because of the ambiguity of the antiquated terminology. The insistence on interpretation instead of pure description also militates against the usefulness of many of the case histories, and the original meanings of many of the terms used have now become obsolete. This may be illustrated by the extreme elasticity and vagueness, even today, of the protean term "delirium."

\section{THEORY OF THE SPECIFICITY OF MENTAL SYNDROMES}

Since 1890 the reorganization of nosologic classification, the animadversions of freudianism and psycho-analysis, and the freedom from pandemics have combined to keep literature on the mental side of influenza almost negligible in amount. There have been a few contributions, such as that of Gosline, ${ }^{22}$ Jelliffe $^{23}$ and others, but none has made any claim to exhaustiveness. There has been, on the other hand, rather a tendency to generalization and to the assigning of categorical principles even before the complete assembling of pertinent details. Thus arose the question of the specificity of mental syndromes with acute infectious diseases, ardently sponsored by Kraepelin and vigorously combated by Bonhoeffer and the French school. Kraepelin's prestige was sufficient to project, even in the face of majority opposition, the thesis that each acute infectious disease could, in the course of further study, be recognized from the mental symptoms alone. This, in short, is equivalent to declaring for the autonomous entity of a variolar psychosis, a typhoidal psychosis, an influenzal psychosis, etc. Except in the case of pellagra (an exceedingly dubious exception), this possibility is not yet recognized, nor is there any general tendency to ascribe the fact that it is not to our failure to read all the signs, as Kraepelin maintained.

22. Gosline: Newer Conceptions of Dementia Praecox, J. Lab. \& Clin. Med. 2:691 (July) 1917.

23. Jelliffe, S. E.: Influenza and the Nervous System, Phil. Med. J. 1041 (Dec. 27) 1902; Psychoses with Influenza, N. Y. Med. J. 108:725 (Oct. 26) 1918. 
It cannot be gainsaid, however, that influenza apparently produces an exceptionally potent neurotoxin. After the last great epidemic, in 1890, Leichtenstern ${ }^{16}$ in his celebrated monograph wrote "This epidemic has taught us something quite new in neurology, namely, an acute infectious disease which compared with all others is characterized by its striking neurotoxic effects. The sentence . . . 'The influenza toxins are intense nervous poisons' has found full justification in the history of earlier as well as in the latest epidemics." Most writers agree with Leichtenstern that influenza is preeminent as an inciter of nervous system sequelae, although Bonhoeffer ${ }^{15}$ and a few others believe in the supremacy of typhoid. But even to the present time there is no proof that these sequelae are qualitatively specific.

\section{THE QUESTION OF PREDISPOSITION}

A corollary question arose which is in a sense more important. This is the question of nervous predisposition as a soil for the psychopathies and neuropathies which arise after influenza. It was Leichtenstern's opinion that “influenza produces a specific nervous toxin which, besides producing conspicuous nervous prostration, in some cases, by its poisonous action on the cortex of the brain, calls forth these psychoses." He points in proof to the two facts, that (1) "the cases observed by us were conspicuous by the fact that hereditary or other neuropathic influences were not found in them, and (2) the obvious frequency with which the young, even infants, were affected by these psychoses." Opposing this view were many writers: Ladame, Mehr, Mispelbaum, Ayer, Justrosinski, Kraepelin, et al. Kraepelin took herein a rather self-contradictory view, for despite his generic theory of specificity, he declared in regard to this particular disease that "it would seem that influenza alone would not be able to produce a disturbance of the mental function in a normally constituted person." Schuele echoes this: "Influenza only plays the part of an etiologic accompaniment in the production of mental disease." And Ladame, "Influenza by itself is never sufficient to produce insanity." Leichtenstern marshals Althaus, Bossers, Mucha and Ulliel as authorities admitting of the possibility of psychoses arising from influenza alone, without "nervous predisposition," and quotes Kirn as having found evidences of predisposition in only 23 per cent. of the cum-febrile psychoses, but in 92 per cent. of the postfebrile psychoses. He attacks the evidences for predisposition in the latter, however, and, to the writer, seems justified.

At present these questions remain much as at the time of this discussion twenty years ago. The recent pandemic of influenza stands in a fair way to settle them. Of the important acute, infectious dis- 
eases occurring in epidemics, typhoid and variola are so well controlled that any large mass of material from which to extract psychiatric data is not to be expected. Plague has not of recent years been epidemic, and the present advance of preventive medicine is not likeiy to permit it to become widespread. Influenza alone remains, and no comment is necessary to remind us of its ubiquity.

\section{THE BOSTON SERIES}

About 120 cases of mental disease with a history of recent influenza were admitted to the Boston Psychopathic Hospital during the last three and one-half months of 1918. (About sixty additional cases were seen early in 1919, and will be presented in future communications.) A statistical analysis of eighty of this group was recently presented $^{24}$ as the first of a series of papers dealing with the subject from this hospital. I pointed out then that on the. basis of statistical indications, the prominent points brought out were the frequency of schizophrenia (dementia praecox) as a postinfluenzal psychosis, the difficulty in diagnosis between delirium and schizophrenia in many cases, the wide variety of psychotic syndromes observed and the conspicuous absence of stigmata of mental predisposition in the majority of the cases.

The answers to the two questions of specificity and of predisposition are thus strongly suggested. But these answers may not be learned from data purely statistical. For one thing, they fail to consider certain essential mathematical fallacies. Thus, 10 per cent. of cases observed in this hospital may have been deliria, but this in no accurate way represents the relative frequency of delirium in influenza or its frequency as a form of mental syndrome accompanying influenza.

Consequently, further study of the data accumulated is expedient, and is herein set forth. Of various modes of attack on the problem of "What forms of mental disease result from influenza ?" an expository analysis by case exemplification lends itself with particular facility. The 120 cases of psychoses in the production of which influenza was an apparent factor, embrace types of all the recognized psychiatric groups, and the data of typical cases constitute the most accessible and forceful negation at hand of the theories of specificity and essential predisposition. The variety of psychiatric manifestations and the varying rôles of influenza, primary, secondary and collateral, appear from the following representative cases.

24. Menninger, Karl A.: Psychoses Associated with Influenza. I. A Statistical Analysis, J. A. M. A. 72:235 (Jan 25) 1919. 
In the presentation of these I have chosen to follow the classification of Southard. ${ }^{25}$ His regrouping of the major forms of mental disease into eleven large categories has the great advantage of convenience. This virtue appears in a comparison of the facility of illustrating the main types of mental disease encountered in the present series. For while it would be quite feasible to illustrate at least twenty of the twenty-two of the psychoses of the American Medico-Psychological Association list (pellagra psychosis, for example, omitted) with influenzal psychoses, it would in no way amplify, except in bulk, the contribution of an illustration of each of the eleven groups of Southard. Without further comment, these appear.

\section{ILLUSTRATIVE CASES}

\section{Group 1.-Syphilopsychoses. Neurosyphilis}

The precipitation of the psychoses of neurosyphilis by acute infections is well known because of the spectacular results rather than because of its frequency. There is a surprising paucity of references to it in the literature, however. The following is one of a series of this type. ${ }^{26}$

CASE A.-Latent Neurosyphilis + Influenza = Active Paresis.

Family History.-The patient was an unmarried man, aged 46, a watchman by occupation, born in the United States. The family history was entirely negative, including an account of the grandparents, uncles, aunts and siblings, except that there were three siblings who died at birth.

Past History.-He had evidently been a healthy, normal child, and graduated from grammar school at 14, entering economic life as a shoe-store clerk. Subsequently he worked in the city fire department. At the age of 32 his thigh and hip were fractured in an accident, and he was given a position as customs guard. He worked steadily until the day he went to bed with influenza. There is no court record. He used no alcohol and no tobacco. Except for the fractured hip his medical history is negative. In disposition he is described as being happy and sociable, with a fondness for music and the theater. The only previous symptom of any kind which was elicited was that he had complained of being tired during the past four summers.

Present Illness. - September 20 , he contracted influenza, which evidently attained a rather severe degree. At one time the temperature was reported as $104 \mathrm{~F}$; ; but returned to normal on the fourth day. $\mathrm{He}$ arose from his bed and was up and about the house, planning to return to work, but seemed to contract "a cold" again and returned to bed two weeks after arising. He was in bed part of the day, but was up the next day, feeling quite well again. That night he became "delirious." $\mathrm{He}$ is described as having been irritable and having refused to take the medicine from the doctor, declaring that it

25. Southard, E. E.: The Genera in Certain Great Groups or Orders of Mental Disease, Arch. Neurol. \& Psychiat. 1:95 (Jan.) 1919.

26. Menninger, K. A.: Influenza and Neurosyphilis, Arch. Int. Med. 24:98 (July 15) 1919. 
was the wrong kind. He hung his head over one side of the bed and let it so remain. He refused to do anything he was told, and announced that the Blessed Virgin Mary was going to tell him what to do. About this time occurred, according to his wife, one-possibly two-brief seizures. He was brought to this hospital, the admission not provoking any severe psychic reaction.

Mental Examination--(Summarized.) His general attitude was that of accessibility and cooperation, although he was at times self-absorbed and agitated, or depressed. His sensorium seemed to be entirely clear. His orientation was precise, except that he had no memory of how long he had been in the hospital. His memory was grossly defective. Not only were many facts of his past history forgotten, but details of all kinds were lost, and his memory for recent events was extremely poor. He recognized short periods of total amnesia occurring during the previous two weeks. His ideation showed fleeting persecutory delusions without systematization, and certain delusions of other types-ideas that his mother was dying, that the Virgin Mary would guard him, that misfortune was about to overtake his family. No hallucinations were elicited. His emotional tone showed, as stated above, instability and, at times, a tendency toward mild, agitated depression; he frequently wept. The thought processes were badly disrupted, but there was no blocking, retardation or acceleration. His motor activity was slightly decreased.

Physical Examination.-This showed the patient to be a poorly nourished, poorly developed man, aged 46, 5 feet, 7 inches tall, weighing 130 pounds. Special senses, epicritic and protopathic sensory interpretations were normal; but deep sensation somewhat impaired. There was no Babinski and no ankle clonus, but a slight swaying in Romberg's position. Knee jerks were equal and active. Pupils were contracted, fixed, and reacted neither to light nor to distance. Corneal and pharyngeal reflexes were present; extra-ocular movements, normal; abdominal and cremasteric reflexes, absent. There was tremor of facial muscles, tongue and extended hands.

Laboratory Findings.-The urinalysis was negative. Blood serum Wassermann test, positive. Spinal Fluid: Albumin, ++ ; globulin, ++ ; cells, 41 ; colloidal gold reaction, 5555555555 . Wassermann test, positive.

Diagnosis.-General paresis. He was committed.

\section{Group 2.-Hypophrenoses. Hypophrenia}

No positive proof in confirmation of the production of Kraepelin's dubious "infectious idiocy" in previously sound material was obtained. This term is a glaring example of Kraepelin's inaptness at nomenclature, as the expression "infectious idiocy" certainly violates all canons of correct designation of mental disease. "Infection dementia," while open to criticism, is certainly more accurately expressive of his meaning. Waiving logomachical contentions, however, we may say that there has been no present evidence of an utter annihilation of mental processes by influenza in nonfatal cases.

Subtotal mental or intellectual loss was, however, definitely demonstrated. The following remarkable case is one of several of a similar 
nature observed. Burr has mentioned having seen several such in a recent report. ${ }^{27}$

CASE B.-Morosis + Influenza = Imbecility.

Family History.-The patient was a boy aged 10, of American parentage. The family history is entirely negative. An only brother, a year younger, is quite well, and is doing fair work in school; he is in the fifth grade.

Past History.-He was born at full term-normal delivery, and had had no severe illnesses. His teeth appeared at 5 months; he walked at 18 months; talked at 3 years, and started kindergarten at 4 .

School Record: (His teacher was interviewed.) He did poor work in kindergarten the first year and was kept there a second year, which is only done "with particularly backward children." He was promoted to first grade, but had to repeat the work, and then, though it was still poor, he was promoted. "His work in second grade was poor but he was promoted because considered too old to stay in the grade." The third grade work was poor, and was repeated this year. . . record, so far, poor. The patient had so far had the very lowest rank given, and was promoted only because of lack of better arrangement, and because of a desire not to keep backward children behind indefinitely.

Disposition: He was always quiet, rather seclusive and played with childish toys which even the younger brother has outgrown. His teacher reports that his deportment is good, and that he does not seem sensitive about his backwardness. There had never been any conduct disorder of note.

Present Illness.-He had influenza for four days, temperature not known. He "slept without waking" for three days, taking no food. The physician and his nurse insisted on his staying in bed a week, which he did without complaint, "perfectly normal and happy" up to this time. Three weeks after the influenza (on Christmas morning) he complained of headache and fatigue, and by his parents' statement "has been out of his head since." (The history was obtained on the 28th.) He cried constantly; wandered aimlessly about; went outdoors and became lost; occasionally sang in a feeble voice numerous popular songs; at other times screamed and cried and refused to remain in bed; said, "I'm lost. Take me home. I will be good to you." His parents were most alarmed because he failed to recognize his mother. $\mathrm{He}$ was brought to the outpatient department and recommended to the house.

Mental Examination.-For the first two days he was constantly blubbering and wailing, the more so when any attempt was made to comfort or quiet him. He selected one of the nurses finally, whose attentions he would permit, and dragged himself about the ward at her heels thereafter, crying when any one else approached him. He did not scream petulantly, but cried as if in grief and begged to be taken home to his mother. He did not express delusions or hallucinations. He was sleepless for the greater part of the first four nights, but gradually slept better at night and cried less in the daytime until, on the fifth day, he was quiet all day, clothed, accessible, and, in a faint way, cooperative. Orientation for place, time and person was retained from the start. His memory defect was most prominently shown in school learning, his knowledge of more general matters being more open to question than his memory thereof. He was tested by the tests used at the Waverley

27. Burr: Mental Complications and Sequelae of Influenza, Med. Clin. of N. A. 2:709 (Nov.) 1918 . 
School for the Feebleminded and found incapable of doing any of the third grade tests, many of the second grade tests, and not a few of the first grade requirements. Thus, to select some of the most glaring deficiencies, he could not count by twos, he could do no subtraction at all, he misspelled "do," "go," "run" and other words little more difficult. He did spell correctly "cat," "it," "and," and "an," and did a few simple problems in addition, such as " $2+3,1+4$, and even $3+7$," but he could not get much above the latter. Ideation was represented by an absence of delusions and an absence of insight. He gave a very inadequate account of his recent trouble, although he did not seem to have had any amnestic periods. Hallucinations were not proved. Thought processes showed no defect of attention after the fourth day; the associations which were rather slow were not schizophrenic, incoherent or erratic, although of course quite puerile. Emotional tone was, of course, a point in question. He was very lonely and nostalgic at first; whether or not this accounted in any considerable measure for his conduct is questionable. During the examination he showed no emotion except when home was mentioned, which evoked a few quiet tears. On the day of discharge he was quite elated and happy because he was going home. Motor Status.-His conduct disorder was confined to the weeping and wailing and screaming of the first few days.

Subsequent History.-On the day of discharge--January 4--his lugubriousness was replaced with smiles and complacency. His memory was again tested briefly and found unimpaired, even for the recent episode; insight, essentially lacking, although he did say that his head was "not right" and that he had been "dizzy from rocking too much;" intellectual processes, definitely, but slightly improved; ideation, as before, and conduct, above reproach. But he took no interest in trying to do ward work nor gave other manifestations of normal initiative.

Physical Examination. - He was a rather undersized lad whose physical examination was negative in all respects save for "a suggestion of hutchinsonian teeth." These were the incisors, particularly the uppers, which had an elliptical or concave contour of the margin, not typically hutchinsonian.

Laboratory Findings.-Urine negative. Blood serum Wassermann test negative. Spinal fluid negative, including Wassermann test

Psychometric Tests.-The patient graded regularly, variation total of 7 , at a mental age of 5.7 on the Yerkes-Bridges Point Scale. On the Stanford Scale, four days later, he graded at 6 years, 2 months. In the supplementary tests his performance in the construction puzzles was poor. The memory tests were also poorly done, and he accepted ten out of ten suggestions. The patient cooperated poorly on the Point Scale and fairly well on the Stanford.

He was discharged with recommendation for instruction in a school for the feebleminded. The diagnosis at discharge was imbecility.

\section{Group 3.--Epileptoses. Epileptic Psychoses}

The final word on the influence of influenza on the production or augmentation of epilepsy should come from the institutions primarily devoted to the care of that disease. The first mention of the matter is probably that of Michell, ${ }^{28}$ who wrote of the epidemic in Holland, 1782,

28. Michell: Antwood over de Febres catarrhales; in Verhandelungen van het Zeeuwsch Genootschapder Wetenschappen te Vlissingen, p. 162; Michell: Geneeskundige Verhandeling over de . . . Febres catarrhales . . . in den Nederlanden, Middelburg, 1875. 
that it "brings about in the brain apoplexy, epilepsy, chorea and convulsive movements." The direct causation of "a typical but chronic epilepsy" which, however, always recovered, has been reported by Landgraf, ${ }^{29}$ Van Deventer, ${ }^{30}$ Jaccoud ${ }^{31}$ and Leichtenstern. ${ }^{16,}{ }^{32}$ Of this type we saw none whatever. Our experience has been quite contrariewise, that epileptic attacks were indeed precipitated or accelerated in known epileptics, but that in no unpredisposed case did they occur for the first time after influenza. The cases of epilepsy, curiously enough, are so generally complicated by other factors, for example, hypophrenia, parturition and appendicitis, that it is difficult to present a good type-case. The following case is interesting for the unusual change after influenza from the typical convulsive seizures to the somnambulistic or twilight-state episodes, and illustrates also an increase in frequency of attacks.

CASE C.-Occasional Epileptic Seizures + Influenza = Epileptic Trerilight States and Increased Frequency.

Family History.-An unmarried American sailor, discharged, aged 22, had a negative family history except that one paternal uncle is said to have had epilepsy. A brother, aged 23, is living and well.

Past History. - The patient was born in Maine; had a normal childhood, and received a grammar and high school education. He left the high school to go to work, but later joined the U. S. Navy and attended a radio school. He was held back one year in high school because of delinquency in algebra and English. He enlisted in the U. S. Navy in April, 1917, and was discharged in March, 1918, presumably because of his epileptic attacks. He admitted having concealed his epileptic history on enlistment, but it was discovered in the Navy and he was held for medical examination in naval hospitals for some months before discharge. Since that time he has been employed at testing steel in an arsenal.

Medical History: This was negative except for epilepsy. He was never seriously ill nor injured. He used no alcohol, tobacco only moderately and denied sexual perversions.

Epileptic History.-Attacks began at the age of 12 ; no particular circumstances of the first seizure could be obtained. Thereafter they occurred about every two months until a few years prior to admission. The attacks entailed the characteristic tonic convulsions, frothing, biting the tongue, etc., but were not extremely severe and, as they were preceded by a somewhat prolonged aura, he had never injured himself severely. They were always followed by a period of headache and malaise, with total amnesia for the events of the seizure. For a year or so prior to his enlistment in the Navy they had been

29. Landgraf: Gesellschaft der Charité-Aertzte in Berlin, Berl. klin. Wchnschr. 1890, Nos. 9 and 12.

30. Van Deventer: Centralbl. f. Nervenh. u. Psychiat. 13:49.

31. Jaccoud: Pathologie interne, Paris, 1870, p. 780 , and Nouveau dictionnaire, etc., Paris, 1873, Part 16, p. 740.

32. Leichtenstern, O.: Influenza Lectures, publ. in Deutsch. med. Wchnschr., 1890 , Nos. $11,15,18,22,23,29,30,42,43$. 
decreasing in frequency, under the treatment of Dr. Waterman of Boston, and during the period of his Navy enlistment, almost a year, he had but two seizures. He was discharged from the Navy in March and between then and November had two or three more attacks.

Present Illness. - September 30 he contracted influenza and was in the Homeopathic Hospital until November 1. He had pneumonia and was not expected to live. During his acute illness he was delirious and did not remember his father's visits. He had no epileptic attacks during the month.

During November and December he had three epileptic attacks. These were of the nature of somnambulisms, however, instead of the convulsive type as previously. He was first noticed by his employer one day to be managing his duties clumsily and when addressed did not reply; so he was taken home, where he subsequently recovered without memory of the event. On another occasion he suddenly left work, taking with him a friend's letter to which he was in no way entitled, and was observed to stagger as if drunk. The third attack was the event of his coming to this hospital. He last recalls being at his work as usual; the police found him wandering the streets in an adjacent suburb of Boston, and failing in satisfactory replies, he was brought by them here. "In the admission office he has to be prodded with questions frequently in order that any answers may be elicited, and to keep him awake. Said he could not tell where he has been living in Boston the past three years. Later replies that he was a radio student at Harvard."

$\mathrm{He}$ was taken to the ward, fell immediately asleep, and when seen the following morning was quite clear, but could give no account of the interval between leaving work the day before and awaking in this hospital.

Mental Examination.-This was negative. He was a well appearing, intelligent, alert young man fully accessible and cooperative. Memory, orientation, ideation, thought processes, emotional tone and motor status were quite normal; there were no hallucinations and no memory of any. He was amnesic for the periods of his épileptic attacks and for the periods during which he was delirious with the influenza and pneumonia.

Physical Examination.-Entirely negative.

Laboratory Findings.-Entirely negative, including spinal fluid and serum Wassermann tests. The psychometric test gave a rating of 17 plus.

Diagnosis.-Epilepsy, twilight state. Not psychotic.

The following case, while not one of the series observed at this hospital, is rather more representative of the general tendency here observed. This case was one seen at Dr. Myerson's clinic at the Boston Dispensary, where the writer was an assistant visiting neurologist.

\section{Case D.-Epilepsy + Influenza = Shozver of Attacks, Then Complete (?) Cessation.}

Family History.-A white schoolboy, aged 14, had a negative family history as far as frank epilepsy or other mental diseases were concerned. The father, aged 45 , was subject to outbursts of temper, and the mother, aged 38 , to chronic headaches, but such ubiquitous symptoms should probably be disregarded. One sister is living and well. Both parents were born in Ireland.

Past History.-The patient was born in Boston, 1904, and except for measles, rubella and chronic tendency to constipation, had always been well. $\mathrm{He}$ was in the seventh grade at 13 , but lost ground because of his epilepsy and was repeating the grade at 14 when seen by us. 
Epileptic History.-In August, 1916, he had a sudden epileptiform seizure which initiated his epileptic history. This and subsequent attacks were generally preceded by aurae of dizziness and "stomachache," and an aggravation of his constipation generally foreran the attacks by several days, sometimes weeks. Just before the fall he was accustomed to see the walls and floor moving.

The attacks have occurred both day and night and in all sorts of places. $\mathrm{He}$ has, however, never severely hurt himself, bitten his tongue, or passed urine. $\mathrm{He}$ lost consciousness totally and had tonic and clonic convulsions. After the attacks, which are of variable duration, he has severe headaches. Occasionally the attacks are mild.

The average interval was given as "two or three months." As he was being treated in the diet clinic for constipation and in the skin clinic for herpes zoster, the attacks were usually noted, and the following dates appear, showing greater frequency: Oct. 10, 1917; Nov. 17, 1917; Jan. 30, 1918; "Is beginning constipated again"-April 24; May 2; June 23; July $15 \pm$; August 12.

Present Illness.-About the last week in September he contracted influenza, was very ill at the City Hospital and bedridden for a month. During his illness he had three, possibly (he himself says) four more seizures. The last was on October 21, while he was still bedridden. Thereafter he was seen in the nerve clinic frequently and had no more seizures. (Seen January 14; no further attacks up to that time.) A physical examination was entirely negative, and a Wassermann test on the blood serum was negative.

Group 4.--Pharmacopsychoses. Psychoses from drugs, alcohol, etc. Paradigm: Alcohol(ism) + Influenza $=$ Delirium Tremens

I recognize the criticism which the presentation as an influenzal process of so prosaic a phenomenon as suggested by this paradigm will provoke. Nevertheless, there is some defense. First of all, it is certainly the most frequent, and, secondly, it is by no means the best understood psychic manifestation of the combined effects of alcoholic and infectious toxemia. It is a considerable question whether the apparent is the real in the case of the suggestions of our paradigm. For all its plebeian frequency, delirium tremens seems far from being completely understood (and we have been awaiting the cry from the alcoholic business interests that the national prohibition amendment has foreclosed the possibility of further study of alcoholic psychoses in this country!). There are not a few (for example, Bonhoeffer) who do not regard the psychosis as a primary result of the alcoholic toxemia, or the direct effect of alcohol on the cortex. Nor is there adequate rationalization for both the excess and the withdrawai incidences.

In regard to the influence of influenza as a specific form of infection in the precipitation of delirium tremens, there are no conclusive data. Rosenbach $^{33}$ thought the epidemic of 1890 was followed by delirium

33. Rosenbach: Berl. klin. Wchnschr., 1890, p. 95. 
tremens of usual frequency and gravity. But "the assumption that influenza on account of its marked neurotoxic character is relatively more frequently accompanied by delirium tremens than any other acute infectious disease, is quite unfounded. . . The frequency of alcoholic delirium [sic] during influenza periods is noted on all sides. (Rosenbach, Nagy, Bruns and others) . . . (But this) is an absolute increase due to the enormous morbidity of influenza and especially to the frequent occurrence of influenza pneumonia." With these remarks of Leichtenstern ${ }^{16}$ we are in full agreement. The essential nature (and etiology) of delirium tremens is still incompletely understood.

Before proceeding to the details of the case to be cited, I wish to mention a particularly conglomerate case which is easily classifiable by means of Southard's grouping, but quite impossible to locate satisfactorily in the twenty-two titles of the A. M.-P. A. Manual. The patient was a successful surgeon, aged 38 , with a family history of multiple instances of insanity on both paternal and maternal sides. He himself had long been alcoholic and had latterly become addicted to the use of morphin, hyoscin, and, possibly, of other drugs. This man contracted influenza and developed thereafter a psychosis as bewildering as the evident etiology, combining symptoms of paranoid schizophrenia and Korsakoff's syndrome. Incidentally, his father is thought to have been paretic, and the patient himself admitted syphilis, but the spinal fluid and the blood serum proved negative.

I will now review one of our typical cases of delirium tremens. Some of these psychoses began during the acute influenza attacks, some immediately afterward, some a few days after supposed recovery from influenza.

CASE E.-Alcohol(ism) + Influenza $=$ Delirium Tremens.

Family History.-A bartender, single, aged 32, born in Massachusetts, had a negative family history.

Past History.-This was negative except for the following particulars: For sixteen years, more or less, he had been alcoholic, and especially so for the past three years. Until three years ago he worked as an egg inspector at $\$ 18$ a week, but later became a saloon porter and later a barkeeper. His own conservative (?) estimate of his average consumption during the last year or two was "two gallons of whisky and beer a day." He freely admitted having been "drunk" two or three times a week for the previous two years, but denied ever having been hallucinated; and he was not a solitary drinker.

Present Illness.-He entered the hospital with a history of having recently had influenza, subsequent to which he became noisy, excited and destructive in reaction to hallucinations. He entered in a hyperkinetic, euphoric state and "would rather sing 'On My Way to Mandalay,' than answer questions." $\mathrm{He}$ was correctly oriented, saying he thought this would be Friday "if it don't rain," and that he was now "in an Influenza Hospital" (which it might well have been taken for at that time). He remained quite disturbed, reacting to 
many hallucinations, but without great conduct disorder until the fourth day, when he suddenly became clear and gave the following account of his present illness, which is established by comparison with outside history to be correct as to known facts.

He begins by asking if he has been in a trance all this time. Says he "just woke up this morning." Is not clear about recent events; thinks it was about the first of October (two weeks ago) that he took sick with influenza. (As a matter of fact it was four days prior to admission and eight days prior to the taking of the history.) $\mathrm{He}$ took to bed, and on the evening of the fourth day (he thinks the second) began to imagine foolish things, heard a band in the house, thought there were robbers in the building, saw the face of a robber in the window, saw "a little coon with a cigar in his mouth and a Quaker Oats box in his hands." The "robbers" remained about, too. He became very frightened, "yelled like hell" and scared the whole household. Threw the cuspidor at "the little coon." Kept the house awake. About 7 a. m. a doctor was called and found him "standing up, all in a sweat, much excited by all that had happened." The doctor sent him here. He remembers coming, being admitted, and being visited repeatedly by the examiner. Has a hazy memory of the whole affair, including many minor details, such as discovering that he had pediculosis pubis, etc.

Recalls also numerous delusions and hallucinations of the same period, and although they were real enough to him, he strangely does not confuse fact and fiction, although he says, "I couldn't swear to it." Some of these delusions and hallucinations were that he was in a saloon where he had once worked, and that a riot was in progress, that he was reprimanded by the "boss" for slack work, that there was a parade in which he was participating, that he was drunk, that a friend named Florence was hiding under a board, that an audience surrounded him, and that "rats, snakes, mice, scorpions and every kind of an animal except an elephant" were to be seen. These he thought he saw en route to the "Influenza Hospital." This morning he woke up and wondered where he was. Finally decided that he had been "in a trance for the past week." Thinks alcohol had much to do with it, and that he had "the shakes" the day he got sick with influenza.

Mental Examination.-After the disappearance of the acute visual and auditory hallucinations and concomitant delusions, no psychotic symptoms were observed. He remained quite clear after the fourth day and was discharged two days later with a diagnosis of delirium tremens, recovered.

Physical Examination.-This was entirely negative except for general tremulousness and a blood pressure of systolic 150, diastolic 105 .

Psychologic Examination.-This showed a mental age of 11.5 years with a variation total of 15, "excellent" performance on the memory tests and an acceptance of only two of ten suggestions.

\section{Group 5.-Encephalopsychoses. Psychoses with organic brain disease}

Comment.- "Cerebral apoplexy has been described as a symptom of influenza in England as far back as the epidemic of 1743. . . . There are no accounts of any postmortem examinations in this period. . . . In 1890 - . . I first called attention to these apoplectiform hemiplegias and monoplegias occurring in influenza. . . . Anatomically there was . . . a focal acute hemorrhagic encephalitis." ${ }^{16,28,34}$

34. Leichtenstern, O.: Primary Encephalitis, Deutsch. med. Wchnschr. 2, 1892. 
Thus does Leichtenstern refer to this interesting phenomenon, influenza apoplexy which "must be regarded as a rarity." He cites cases reported, in addition to his own, by Virchow-Senator, Fuerbringer, Koenigsdorf, Schmidt, Erlenmeyer, Gross, Eichorst, Stembo, Remak, Drasche, Bilhaut, Prentis, Herzfeld, Warfvinge, Brakenridge, et al. Two cases reported by Straumann are cited which resemble the one here recorded "(fever, coma, death) . . . most readily classified under the . . . form of acute encephalitis without motor manifestations or motor paralyses." The pathology and a short discussion of the various forms is given, but he does not speak of definite psychoses accompanying or preceding the other manifestations, as hereinafter related. Michell's ${ }^{28}$ comment on the production of "apoplexy" by influenza has been quoted above. Oppenheim ${ }^{35}$ refers in his textbook to his own work and that of Struempel, Lichtenstern and Fuerbringer, and gives a good description and photograph of the lesion. He does not discuss psychotic accompaniments.

Up to the present time the 1919 literature has contained no other reports of postinfluenzal hemiplegias (encephalitis hemorrhagica influenzae). In an address at the meeting of the Association of American Physicians at Atlantic City, June 16, 1919, Major J. W. Hall of Denver casually mentioned two cases seen by him in the course of his military medical work in the training camps of the southwest. In a personal conversation he stated that both cases were sudden hemiplegias occurring in young male adults during convalescence from influenza, one while straining at stool, and the other under circumstances not recalled. An effort is being made to collect details on these exceedingly valuable cases.

A few other instances of encephalopathic psychoses with an associated influenza were observed in our series, including one other instance of cerebral hemorrhage, but in a case psychiatrically diagnosticated manic-depressive psychosis with good symptomatic basis.

It may be demonstrated later that encephalitis lethargica should be placed in this group of encephalopathies resulting from influenza. At the present time opinion on this point is sharply divided, and in order not to confuse the present issue, encephalitis lethargica (as opposed to encephalitis hemorrhagica) is not discussed or illustrated here.

CASE F.-Normality + Influenza = Atypical Psychosis, Proceeding to Death from Cerebral Hemorrhages (Hemorrhagic Encephalitis).

Family History.-The patient was a woman, aged 43, married, born in Italy. She had lived in the United States eighteen years and did housework. The history of her grandparents was negative. The father died of pneumonia at

35. Oppenheim, H.: Textbook of Nervous Diseases, translated by Bruce, London, 1911, p. 825. 
73 ; the mother at 65 of an unknown cause. A paternal uncle died of heart trouble and his sister suddenly of unknown cause. A maternal brother killed himself while drunk (?). There are four siblings living and well, none dead. No mental, nervous or epileptoid disease was acknowledged.

Past History.-The woman had been taught in Italy to read and write, but little more. She was always a healthy child and was never in a hospital. She was married at 27 to a man of 46 , and the union was happy and fruitful. There are nine children living and well; one died of acute indigestion. There were no miscarriages, no known mental defect in the children.

She never did other than housework. Her personality is described as being "quiet, not inclined toward recreation, but prefers to stay at home. Goodnatured, and a good housekeeper. Normal interest in her (Catholic) religion." She was not alcoholic.

Present Illness.-Until September 10 the patient was considered well in every respect. On that date she went to bed with an acute attack of influenza. There is some question as to the duration of this disease. She is known to have been febrile for two succeeding days. She then tried to get up, but had "a spell" of an hour's duration during which she was tremulous, "nervous," suffered from palpitation, and had a fear of death. That night she was unable to sleep for fear, and this symptom persisted. She was taken to a general hospital and spent fifteen days there, during which time she was constantly agitated and querulous, complaining of multitudinous vague pains in stomach, head, etc. She went home and remained in bed for two weeks; then she was up and about for some six weeks more before being brought to this hospital. She was thought by her relatives to exaggerate trivial symptoms; she complained constantly, believing her digestion impeded, that she was hopelessly constipated, and that she could not possibly live. She made many pretended attempts at suicide and finally one confessed bona fide attempt.

There were no avowed hallucinations, no observed fainting attacks and no convulsions; and there was no delirium, no known amnesia, no fibrillation, etc. It was about ten weeks after the onset of the influenza that she was brought to this hospital.

On the day of admission, when she tried to cut her wrist vessels, "she was excited for the first time, and pushed her husband away and did not want to see any one." The admission, notes at this hospital, condensed, read as follows:

"Patient is an agitated and apprehensive Italian woman who answers questions promptly and accurately. Since influenza in September . . . she has been depressed, afraid she would die, worried over her physical condition. 'I feel sick all time. I think I die. If I shut my eyes I see bad people with big eyes. If I go to sleep I wake up and worry and think never get well. It all is come for my stomach. If I eat I feel bad; if I don't eat my stomach empty, I feel better. My nerves are all excited and my nights are terrible.' She complains of palpitation, constipation, and insomnia in addition. No conduct disorder, and no frank evidence of depression."

The ward notes made thereafter state that no change in general demeanor occurred.

Mental Examination.-Appearance and behavior were as given above. Her orientation was precise. Her memory was not defective either for recent or remote events. She gave the full details of her family and past history, as 
well as of the present illness in accordance with the outside history as related. In regard to hallucinations, she declared that when she closed her eyes at night she saw the faces of dead people and others. This frightened her more than ever, but the visions disappeared when she opened her eyes. The visions did not speak to her-there were no auditory hallucinations. Ideas and Judgment: Delusionary formation and lack of insight may be noted from the above account. Her thought processes showed no manifest abnormalities of attention, associations, or train of thought. Retardation was not present. "She speaks in a rather melancholic tone, whispering at times. Emotionally, she is more apprehensive than depressed, and greatly worried. At times she smiles pleasantly, but there is no schizothymia." Her motor status showed mild hypokinesis with no further conduct disorder.

Physical Examination entirely negative, except that the knee jerks were not obtained. Blood pressure, systolic 118, diastolic 70 .

Laboratory Findings.-Urine, blood serum Wassermann test and spinal fluid examinination, including Wassermann test, negative.

Course.-It is interesting to note that on the fifth day after admission the staff made the following vote on the diagnosis: Psychoneurosis, 2; manicdepressive psychosis, depressed phase, 1; undiagnosticated psychosis, 4.

On the 19th, six days after admission, she was found to have a pulse of 140 , a temperature of 104 , and was apparently unconscious. In this condition she remained for over two days and died.

A necropsy was performed by the assistant pathologist to the Massachusetts Commission on Mental Disease, Dr. Myrtelle M. Canavan, and the brain in toto and in section was examined by the pathologist, Dr. E. E. Southard. The chief findings were: An extensive cerebral hemorrhage of large size with evidence of many petechial hemorrhages throughout the cortex, and bloody fluid in the third ventricle. There were numerous "flea-bitelike dots" of blood between which the tissue was softened and of a gray to grayish-red color, as described by Leichtenstern. In addition, there was chronic fibrous endocarditis of left auricle and of mitral and aortic valves, old pleuritis, purulent bronchitis, gallstones in duct, slight vascular nephritis, aortic sclerosis, petechial gastric hemorrhages, hemorrhagic uterine lining, acute leptomeningitis.

Group 6.-.-Somatopsychoses. Psychoses with somatic disease.

Delirium in all its polychromatic variety may be proposed as the representative symptom of this group. In so declaring we elude the pregnant question of just what delirium really is. In the paper previously mentioned ${ }^{24}$ I have made a plea for the readoption of the simplest of classifications for delirium, namely, one based on the time of onset with respect to the fever, of which it may, indeed, be entirely independent. Thus all deliria associated with infectious diseases may be designated as either prefebrile (cum) febrile, or postfebrile, and in such a designation there is the added value of a prognostic index. The postfebrile forms are proverbially difficult of diagnosis and grave in prognosis. The fourth form, afebrile delirium, does not enter into the present discussion.

The fact that no form of mental disturbance is more familiar than what is termed "febrile delirium" is far from equivalent to saying that 
it is the best understood. The descriptions of its essential nature are widely variant; even now there is no agreement on its pathognomonic signs or symptoms, and many - the writer included - are inclined toward agnosticism in point of pathognomonic indices, and to doubt if any such exist. Part of our difficulty herein may be referred to the psychologists, who have not yet decided just what we should believe as to the nature of consciousness; but perhaps an even greater blame falls on psychiatrists themselves for the confusion arising from the use of inaccurate, ambiguous and indefinite terminology and nomenclature.

Of the various forms of transient mental disturbance whose general character fitted the hazy outlines of the psychosis "delirium," certain types were particularly striking. The "muttering delirium" of historic fame, the "typhoidal delirium," the acutely maniacal forms of delirium with homicidal tendencies, types simulating Korsakoff's syndrome, delirium without disorientation, and divers others were encountered. Two types deserve special mention. In not a few cases there was a history of wandering about the neighborhood unable to find the way home, pounding on the doors of houses in alarm or terror, disappearing from work or home and later discovered by the police, amnesic and disoriented. These usually occurred during convalescence. An informal and unofficial report from the medical officers of a certain naval prison is to the effect that a number of the prisoners provisionally classed as "deserters" absconded during the convalescent period following influenza, and it was found that some of these, at least, were amnesic for events of the period and represented, in the minds of the naval medical officers, additional instances of postinfluenzal twilight states.

A second unusual form of delirium is what might be denoted delirium schizophrenoides, the schizophrenic elements dominating the picture to such an extent that the differentiation from dementia praecox in the cross section was quite impossible. This type seems to have been exceedingly frequent after the recent epidemic, as it is mentioned in practically all of the reports on mental sequelae of influenza which have appeared. (Burr, ${ }^{27}$ Egbert Fell, ${ }^{36}$ Harris $^{37}$ and others.) Because of the frequency of this type in our series, and the remarkable configuration of the clinical picture, it is this type of which I have chosen to give an illustration. The following may be considered a representative example of this type.

36. Fell, Egbert W.: Postinfluenzal Psychoses, J. A. M. A. 72:1658 (June 7) 1919.

37. Harris, A. F.: Influenza as a Factor in Precipitating Latent Psychoses and Initiating Psychoses, with a Brief History of the Disease and Analysis of Cases, Boston M. \& S. J. 180:610 (May 29) 1919. 
CASE G.-Normality (?) + Influenza = Delirium; first maniacal, then schizophrenic, then depressed, then stupid; finally disappearing.

Family History.-The patient was a woman, aged 34, a Nova Scotian, married and had always done housework.

The paternal grandfather died at 72 of pneumonia. He was a Nova Scotian fisherman. The paternal grandmother, a "kind, sociable, Christian woman," died at 93 of pneumonia. The maternal grandfather died at 72 of Bright's disease; the maternal grandmother, at 64 of a tuberculosis which she was known to have had many years. Her father was a carpenter 62 years old, a church deacon, said to have cancer of the lip. Her mother, the chief informant, seemed to be intelligent and well informed. She thinks she has had heart and kidney disease for some ten years. The uncles were chiefly sea-faring men; those who were not drowned are in general still alive and well. A maternal sibling died of tuberculosis of the brain; a paternal sibling of consumption. Aunts numerous, nothing of importance. Siblings: Brother, 37, well; the patient, 33; sister 31, with two healthy children; sister, 29, with three healthy children and one dead from tuberculosis; sister, 19, died of tuberculosis; sister died of pneumonia at 3 ; sister, 22 , well. No known mental or nervous disease in any branch of the family.

Past History.-The patient was born on the Nova Scotian coast in 1886, and lived there until the age of 22 , when she came to Boston and has lived here since. Educational: She attended the grammar and high schools from the age of 6 to 17, with a good record throughout. Habits: No alcohol nor tobacco; her meals were regular, and her exercise fairly regularly.

Personality: "Active, lively, talkative, high spirited, kind, practical, independent. Fond of music, is much interested in the Eastern Star fraternity. Member of Baptist church." Later we were told, however, that she had always been extremely suspicious. Marital: She had been married four years prior to her present illness. Her husband was a rather egocentric individual, "demanding more than he gave." The union was happy, however. A child, born less than a year after marriage, is well and strong, although he had influenza and pneumonia along with his parents. Medical: Except for the diseases of childhood, the patient had no serious nor protracted illnesses except typhoid fever, which she had at the age of 14.

Present Illness.-Husband and wife were taken ill with influenza about November 17. On November 24 the husband died. Even before his death, the patient began to show definite evidences of psychosis. "The room was filled with the Holy Ghost." "The spirit of God" told her he would not die. She kept saying, "Don't you feel the stillness?" and made the family pray with her constantly.

The day after her husband's death she was up and out of the house, seemed fatigued, talked less, and was less religious. The following day she spoke of having died, gone to heaven and returned; insisted that she was God, and wished to convert everyone. The following day she went with her sister to attend to some business. She seemed alternately dreamy, deluded, semi-conscious, and in a state of complete clarity. On the evening of the latter day she showed evidences of great fatigue, "continued to scream, laugh, sing hymns, and wanted others to do so." This continued for the next day or so. She then began to claim supernatural power, talked of striking people dead or blind, insisted that she was God, and her child the devil. Because of her threat to show what she would do to "the devil" she was brought to this hospital lest she injure her baby. She was brought by the police. 
Mental Examination.-On the day of admission the patient manifested great excitement. She was constantly talking, shouting, or singing. A sample of her discourse at this time follows:

"Now I wish you to know that at this present time I am God. I am God. I am God. You understand, I am God. God says, 'Now let us sit down and reason together. Laugh and the world laughs with you.' Weep, now Father, I don't want to do that. God so loved the world that he gave," etc. (Where does that come from?) "The Book of God, do you know that?" (Then sang one verse of The Light of the World Is Jesus.)

(Why do you assume the personality of God?) "Write down for me the word G-O-D, God. You are fully convinced that I can see who I am, are you? Before I get through with you I will convince you that you don't know who you are, but $I$ know who I am. I am $M-M-M$, and God is speaking through me. No, I am a scientist, I am only a Christian girl. The Blessed Virgin is right there with God, yes, she talks to me too. I can see them both either in daylight or at night. I have a mission on earth, it is to bury my husband, N-N-N."

At this time she was correctly oriented as to time, place, and, nominally, for person. Her replies to questions, while frequently irrelevant and incoherent, indicated that her memory for recent events was "not appreciably impaired." Her ideation showed expansive, delusionary formation, centering about a transformation of personality. Her insight did not extend beyond declaring that she was "a religious fanatic." Her thought processes showed unstable attention, loose and incoherent associations, and an accelerated train of thought without true flight of ideas. Irrelevancy in her replies was less common than incoherency in the statements themselves. At times she became obscene and profane. Her emotional tone was one of excitement, expansiveness, agitation without apprehension or elation. Her motor status was that of hyperkinesis in rather narrow limits. She was exceedingly untidy and kept her room and her clothes soiled.

This description is representative for the first five days of her stay. Thereafter the picture changed, as will be detailed below. The record of the following conversation was made on the fourth day toward evening, when she was rather less disturbed than usual. Except for the queries indicated in the parentheses the matter was entirely spontaneous.

She is in a private room, constantly jabbering and shouting, running about the room, crouching in a corner, or gesticulating. A stench of fecal and other origin fills the room. Her gown is soiled with a menstrual discharge, on which fact she comments unabashed. When the examiner opens the door she forces her way past him and leaps on a bed in the corridor. Here she perches immovable, silent for a few minutes at a time, but bursting out at frequent intervals in a senseless and incoherent comment on some word or phrase caught from an adjacent patient who is in a pack and much disturbed. (What are you doing?) "Why, I am rowing a boat. I am on to Bermuda. What you writing? (Snatches notebook.) Why don't you go and get me a glass of water? There, there, that's what it is. I am telling you what the nurses are doing. I will now convince you that I am not blind. You know damn well that I am going to unbraid my hair. If I get there. . . . You know damn well that . . . here . . . there . . . (her loosened hair falls over the bed railing). This is the fountain of life. Don't you touch that or I'll drive you through the wall so quick you won't know whether you are a bird or a nurse! Why, I told them you got all those supreme beings and the birds 
and. . . . See! See! That's what they do! Isn't it terrible! (Jumps on bed and assumes threatening attitude, but is quieted by nurse.) Get out of my way every damn one of you! Don't you dare to take that out of my mother's lips tonight, and I think it's a damn shame that I am still without that glass of water. You damn nurse I'll slap your face in a minute! You'll find your birds on that boat Bermuda, and I'm still without the glass of water. I want a drink, you damn fool. (Overhears the word "skeletons.") I'll tell you who will be skeletons around here; the doctors and nurses. I'll poison every one of you. And I'm still without that glass of water. P, I, S, S, there, I'll call you a damn sweet doctor." (Nurse walks by.) Nurse says, "Excuse me." Patient replies, "Oh, you damn fool! (mimics) 'Excuse me, excuse me, excuse me,' what's that for?" (Water is brought. She obeys orders to keep her hands down and drink from the cup held by the nurse. Stops between draughts to say-) "And I'm still sitting here trying to get a drink of ice cold water. (Spits on the floor.) Now you are fully convinced that I did not have that glass of ice-cold water. (Supper is brought. She asks for sugar, is told that there is none, says all right she will drink the tea without it. Examiner remarks that she is a "great girl.") "You bet I am. That's the trouble, it's mind over matter. (Bursts into tears.) I'm crying to think I was treated so for calling you the sweet-faced doctor." (She hears another patient singing, and herself breaks into song, but in another key and tune.)

Physical Examination.-At this time the physical examination was essentially negative; the urine negative; the spinal fluid negative; Wassermann reactions on blood serum and spinal fluid negative.

Course.-The excitement gave way to a phase of inert apathy. She wandered about the ward, quiet and well behaved. She obeyed orders, retained her clothes, associated with other patients, but was rather noncommunicative, played the victrola, and was rarely or never talkative after the tenth day. On the fourteenth day irrelevancy, incoherency, inadequacy characterized her replies. Thus:

(What does God say to you?) "What's wrong? Nothing's the matter."

(What is the trouble with that girl?) (indicating a patient.) "I can only answer for one."

(Are you clear in the head now?) No reply. She stares inquiringly; glances furtively about.

(How do you feel today?). "It was, yes sir. Better."

(Are you better?) (After a pause) "My breath is very offensive."

On the sixteenth day she was quite disturbed in the forenoon, but toward evening became more composed. Cried when her husband's death was mentioned. Answers still illogical, irrelevant, incoherent. No insight. She talked a little of having been "a religious fanatic," but the words seemed to have no real meaning for her.

On the eighteenth day she was interviewed in continuous baths and was quiet and accessible. (How long have you been here?) "You know me as well as I know myself."

(What is that in your hand?) "My handkerchief."

(Why have you wadded it all up so?) "Why mother gave it to me."

(Why are you in the bath?) "She said it was necessary" (pointing to the nurse.

(Are you suspicious, Lillian?) "Of you?"

(Of any one?) "No." (Pause, looks at nurse) "But I know she don't dare wink any more." 
(What?) "I said she wouldn't pull my hair again."

(Did she do so once?) "Ask her. Let her speak for herself. "Speak for yourself, John.'-Miles Standish."

During the next week the patient seemed more and more quasi-normal, the chief symptoms being restlessness and the occasional expression of paranoid ideas. Irrelevancy and incoherence in her replies disappeared almost completely. A certain tendency to evasiveness was noted. About this time she was asked to write her version of her trouble, and wrote the following account:

"I was suffering from severe headaches for over a week and had been without sleep for one week previous to being brought here. I was so disturbed in my mind about where my husband's soul would go that I prayed with my Maker and asked for His help in my afflictions. I felt my prayers were being answered and I felt the presence of God around me. All people would say was 'sleep.' I became somewhat of a religious fanatic and heard voices speaking inwardly. I quoted passages of scripture and the Twenty-Third Psalm ran through my mind. I talked to those around me and spoke of the teachings of learned men that I had heard preach from the Bible. One day, in taking my baths, I spoke of Billy. Sunday and told one of the patients about it. I was somewhat emphatic in assuming so much Godlike spirit, but my nerves were somewhat unstrung, and while I still feel the need of prayer I am able to control my nerves and know that $I$ have been helped in my treatment here. It all came from my mind being overtaxed by thinking so steadily. But thanks to all around I feel my feet are on terra firma once more and I realize how disturbed I was."

Condition on the Thirtieth Day.-The patient had been transferred to the quiet ward and was daily employed in ward work and occupational therapy. She seemed, superficially, quite normal, with partial insight as to her recent mental trouble. She recalled many of the incidents, but was unable to recall many others. She claimed to have regained entirely her old interests and affects and was complacently waiting to be discharged.

Certain residual symptoms remained, however. A nurse's note is quite expressive. "Patient depressed at times. Cries easily, but says she is strong enough to go home. Seems suspicious. Thinks conversation of others is directed toward her. Asks the same question several times."

Moreover, she seemed somewhat slow in grasping the situation. She doubted if she were really to go home as had been announced to her and cried at the realization that it was true. She lingered about the ward office as if fearing something might be said about her. Her psychometric rating, moreover, gave her a mental age of only 13 -on Point scale; $137 / 12$ on Stanford.

She was discharged on the thirty-first day, virtually, although not technically, against advice, improved but not recovered. The diagnoses varied widely, ranging from cyclothymic psychosis to dementia praecox, according to the period of consideration. On the whole the case seems to be quite representative of one of the polychromatic forms of postfebrile (influenza) delirium.

Subsequent Report.-Two weeks after discharge the patient reported. At this time she betrayed a peculiar paranoid state difficult to define. The following conversation is illustrative of the irrelevance, inadequateness and suspicion which characterized her manner. She insisted that she was perfectly well (as did also her mother).

(We are in doubt as to how much can be remembered by delirious patients. Will you help us? How much do you remember?) "Well, I shouldn't remember everything, should I?" 
(I don't know, do you?) "Well, it should be a little hazy, shouldn't it?"

(I don't know, is it?) "Well, to a certain extent."

(To what extent?) "Well, I don't suppose I remember everything. Can you remember everything that ever happened in your life?"

(We want you to come in and do another psychologic test.) "What for?"

(I think you could do one perfectly now. You didn't before.) "Yes, I did."

(No, it wasn't so good.) "Well, let some one else do it. You do it for me."

(Did you think you were God?) "I never said that."

(Yes, you did.) "Doctor, I never said that at all."

(You admit that you don't remember everything.) "Well, I didn't mean what you mean."

(You admit that you said you were God?) "I didn't."

(But we have it written down.) "Oh well, that's different."

(But you said it, you know.) "Well, I didn't mean what you mean. You can't read my mind and I can't read your mind No one can know what I felt unless he has been at death's door. Have you ever been at the brink? That's where I was. I had only a flicker of life. I felt my pulse--it was very slow-about 40."

(Was it then that you heard and saw God?) "I said I was the armor of God . . . I had . . . that's what I said."

(What did you see?) "I saw everything."

(Spirits?) "Yes."

(What were the spirits like?) "Doctor, don't you have a conscience? Doesn't your conscience tell you things? That's what it was."

(Did you see angels?) "Yes. They weren't like you, though, Doctor, not like you, waving around in the air."

(What were they like?) "Doctor, you can't experience it unless you have been at death's door."

(I don't want to experience it. I want to hear about it.) (Reply was inadequate-details forgotten.)

The mother seems to be an intelligent woman who appreciates the evasiveness and paranoid trend of her daughter's replies, but says that she has been that way from childhood up. "As a child she was suspicious and I had to take care lest her feelings be hurt by trivial things that didn't concern her.- If I spoke quietly to one of the other children, she would suspect that I was talking about her. She is absolutely the same now as she has always been. You have to know her to understand her ways. That is her, all over."

The further course of this case will be recorded in a later article of this series dealing with delirium and its relation to schizophrenia. For the present it serves admirably as one of those baffling cases, of which we had so many, wherein there was a constant battle between the protagonists of a diagnosis of schizophrenia paranoides and the advocates of the simple designation delirium (schizophrenoides).

Group 7.-Geriopsychoses. Psychoses of senile and presenile periods

In a post graduate lecture in 1893 Gowers ${ }^{38}$ mentions a case representative of many others wherein full mental vigor was replaced by utter dementia in a senescent individual. The influence of the acute

38. Gowers, W. R.: The Nervous Sequelae of Influenza, Lancet 2:1 and 73, 1893. 
infections is vaguely enough understood at best, and our knowledge of the effect on the mental diseases of old age is the least favored in point of available material. The following example speaks for itselif. The writer is quite conscious of the deficiencies in diagnostic data, but the known facts are strongly indicative on the basis of probabilities.

CASE H.-Senescence + Influenza = Senile Psychosis, Paranoid Form.

Family History.-A married man, aged 61 , born in Maine in 1859 , had a negative family history.

Past History.-He had had the usual children's diseases, but no severe illness nor convulsions. After a cursory education he entered the shoe business and remained at that work consistently the rest of his life. Habits: He had been a total abstainer from alcohol. Marital: Married for forty years to one wife who died of "creeping paralysis," and for two years to a wife who is living and well.

Present Illness.-The patient was a Christian Scientist whose orthodoxy prevented his consulting medical advice and likewise prevented our acquisition of a good account of his trouble. The following admission note gives all that was ascertained.

"Influenza began approximately October 19. Although not bedridden, he was feverish for several days. Mental symptoms appeared a few days afterward, about ten days before admission, rather insidiousiy. According to his wife and a friend, extreme talkativeness, restlessness, insomnia, and delusions of government inspectors pursting his friend are the chief symptoms. In the admission office he was very indignant, having been brought by strategy, and insisted on having it explained why he was brought, what the disturbance was all about, etc. He talked at a great rate about his unblemished record, and made remarks and hints which referred to the delusions above mentioned, but denied them when flatly put to him. Absolutely no insight. He has a marked aversion to doctors and hospitals. Quite resistant on way to ward."

The physician who examined him on the ward noted: "He is a very talkative and extremely irritable man, who can give no reason for coming here, but demands that some explanation be given him. He refuses to admit anything, even that he has just had influenza. Very circumstantial and rambling in his conversation. $\mathrm{He}$ is apparently well oriented and his memory seems very good. No delusions or hallucinations are elicited. Very irritable. Radial arteries markedly palpable."

Mental Examination.-After the day of admission depression, humiliation. and chagrin replaced the irritability and disagreeableness. He was a rather pitiful sight, sitting about the ward in great dejection, and while superficially accessible would give no adequate expression of his ideation except that friends had wronged him. His thought processes showed marked circumstantiality, occasional irrelevance, and a distinct tendency to wander from the subject at hand.

Emotional Tone-Depression, irritability and agitation were represented at different times. No considerable amnesia, disorientation or disturbance of motor status and no hallucinations were ascertained. No further data concerning the delusions were obtained than those mentioned in the admission note, save that he was fearful that something would happen to him here. 
Physical Examination.- - He was fairly well developed, but poorly nourished; his hearing was slightly impaired; he had a slight tremor of the tongue, normal reflexes, no teeth. His lungs showed fair resonance throughout, except for a slight dulness in the right base, numerous râles in the left back, and a reputed friction rub in the left axillary region. Heart: The apex was felt in the fifth space. The right border was 2.5 c.c. to the right of the midsternal line; the left border, 9 c.c. to the left. Aortic and pulmonary sounds were of good quality; no murmurs were heard. The pulse was equal, regular, and synchronous. Arteries (temporal and radial) were tortuous and sclerosed. There was a pulsation of the neck vessels. Numerous dilated capillaries were found on the legs. The blood pressure was from 150 to 76 . The physical examination was otherwise negative.

Laboratory Findings.-These were entirely negative, including urine, spinal fluid, and blood Wassermann test.

Course.-A lumbar puncture was done on the sixth day. He was kept in bed twenty-four hours thereafter. On the eighth day he complained of a little headache and some nausea. He made no other complaints and went to bed as usual on the evening of that day. At 8:30 p. m. the nurse entered his room and spoke with him. He was quiet, and there was no complaint. He was seen at least twice during the night by attendants, and nothing unusual was noticed. At 6:30 a. m., November 9 , as he had not arisen when the other patients arose, the nurse went to call him, entered his room, and found him dead.

The medical examiner was notified and inspected the body before its removal from the bed or the room. He expressed the opinion that death was due to cardiovascular disease and did not recommend a necropsy. Whether or not this diagnosis by inspection postmortem resulted in a correct physical diagnosis, the fact remains that the psychiatric diagnosis of psychosis with cerebral arteriosclerosis is not tenable. Neither the amnesia nor any evidences of focal or general cortical irritation impairment, or destruction, were present. On the other hand, the vague persecutory delusions, the total absence of insight, the irritable, depressed and agitated emotional tones, plus the history of insomnia and restlessness, together with the age of the man, make a diagnosis of senile psychosis of a paranoid form the most reasonable hypothesis.

\section{Group 8.-Schizophrenoses. Dementia praecox}

The conception of schizophrenia as delimited by Kraepelin ${ }^{39}$ and elaborated by Bleuler, ${ }^{40}$ was not in the psychiatric mind at the time of the last great influenza epidemic. Consequently, there is not in the literature any elaborate discussion of the role of influenza in the production of the picture of dementia praecox. And, as stated in the introduction, no other acute febrile disease occurs in sufficient ubiquity and sufficient numbers to make possible accurate comparative study of its psychic effects under uniform extraneous conditions.

That influenza may be followed by schizophrenia is mentioned directly in a few instances, and indirectly rather often. Thus, Sir William Gowers" wrote in 1893: "Just as the depression develops

39. Kraepelin, E.: Psychiatrie, Ed. 8.

40. Bleuler: In Aschaffenberg's Handbuch, Leipzig and Vienna, 1912. 
into melancholia, so the delirium which occasionally attends the acute affections may have for its special sequel chronic delusional insanity (read dementia praecox) and, very rarely, acute mania." Again, without entering into a discussion of the proper distribution of the entities composing the heterogeneous, ill-defined and fortunately obsolescent syndrome "amentia," it will be recalled that Kraepelin pointed out that many cases so diagnosticated proved to be dementia praecox, and that Régis ${ }^{41}$ regarded a prolongation of "Confusion Mentale" (essentially the same concept) as practically identical with one of his two forms of dementia praecox (constitutional and incidental). And as "amentia" and "mental confusion," etc., are frequently mentioned as sequelae of influenza in the older literature (including Régis' textbook), one may presume that the occurrence of dementia praecox after influenza. although frequent, by a confusion of nomenclature escaped signalization.

The few authors who mention it specifically do so with an apologetic manner, generally ascribing its occurrence to a coincidence. Kirn, Bonhoeffer and others mentioned above have referred to it, but generally add reassurance that definite stigmata of psychotic tendencies were previously manifest, or were apparent in the family history. Paton $^{42}$ remarks the occasional precipitation of Schizophrenia by influenza, but ascribes to it only a minor rôle.

These writers were in general still strongly influenced by the functional conception of Schizophrenia. The great majority of them were primarily clinicians. And because of the greater availability of material, the protagonists of the organic basis have attacked the problem almost altogether from the pathologic side. In the specific instance of influenza, Gosline ${ }^{22}$ reported a series of necropsies with histologic brain findings, and pointed out the similarity of findings in a case of influennza with delirium, and cases of dementia praecox, drawing the obvious inference, "that . . . certain cases of dementia praecox are due to infectious or toxic processes."

Perhaps the organicists have overlooked what might seem to give considerable weight to their thesis, accruing from the clinical side, as observed in the recent epidemic, and in the present series. In the statistical study previously mentioned ${ }^{24}$ I pointed out the surprisingly great numerical incidence of schizophrenia, and concluded that "an organic basis for some instances of the picture denoted dementia praecox is supported by" this and other facts of that series.

41. Régis: Psychiatrie, Paris, and, Délire de la convalescence, Ann. méd.psych., Paris, 1883, p. 393.

42. Paton, S.: Psychiatry, Philadelphia, J. B. Lippincott Co., 1905. 
I now propose to present typical instances of this phenomenon.

Because of the emphasis placed on the matter of predisposition by most writers, two types of cases are recorded. The first two with a history satisfactorily demonstrating a tendency toward the seclusive and egocentric; and the third one clearly without any such stigma. As cases similar to both of these types were, as previously reported, by all means the most common forms of mental disease, the choice is rather wide. Many of the cases, however, have minor complicating factors: the history of a recent miscarriage; an incomplete record of the past history; defective laboratory reports, etc. In general, the cases are quite representative and fairly complete. Two instances of the precipitation of second attacks of the cyclic form of schizophrenia occurred. These are not here illustrated.

CASE I.-Predisposition (egocentric temperament) + Influenza $==$ Full blozem Schizophrenia.

Family History.-An unmarried nurse, aged 35, was born in Massachusetts. Her grandparents were born in Ireland, of whom there is no history. Her parents also were born in Ireland. Her father died at 65 with pneumonia, the mother, at 67 , of shock. There were paternal and maternal siblings, of whom there is no history. The patient's siblings: two sisters, living and well; one brother aged 38; a twin sister died of gallstones. A nephew died of tuberculosis. No history of mental or nervous diseases in the family.

Past History.-The patient was born in a Massachusetts village. She graduated from grammar school. Not much is known of her childhood. At 26 she graduated from a nurse's training course and since that time has been a visiting nurse for the Boston Consumptive Hospital. Medical: The patient suffered a Colles' fracture five years previously and was described as having had "neuritis" for a period of seven months three years ago, which was connected in some way with her diet. "A stomach trouble" which was suspected by her friends to have been neurotic, had been complained of for many years. Habits: She took no alcohol whatever. She paid much attention to treating herself and lived on a special diet because of this "stomach trouble." Her work gave her a reasonable amount of exercise.

Personality.-The patient is described by the superintendent of nurses, who had known her for eight years, and who seemed to be an intelligent, reliable and observing person.

"She talks continually about herself. She has always been egotistical, selfish, self-satisfied. She is not popular, but she continually talks about herself and she was always looking for sympathy. No matter what subject is brought up she will invariably bring it back to her own illnesses. She has a few friends, but is definitely seclusive and does not go about with them much. She is loud and noisy in her actions, speech and laughter, and her laugh is empty, forced and hysterical. She poses as younger than she actually is and never realizes her age. She is either way up or way down. She is stingy with money, except for herself, and spends much on dress. She is a devout Roman Catholic."

Present Illness. - She contracted influenza on September 28. She had a high fever which disappeared on the fifth day. It is thought to have been as 
high as $104 \mathrm{~F}$. and known to have been 102 , but she was at no time delirious. On the third day she seemed quite hilarious, saying that she had the influenza and might as well make the best of it. The next few days "she began to worry about her treatment as usual."

By the time her temperature had returned to normal, she was distinctlyt psychotic. She is thus described: "First she would be rigid and staring and would not speak. She would relax if grasped by the arm. At other times she would talk a blue streak. This was not irrelevant or incoherent, and she could tell the doctor accurately what happened during the previous twentyfour hours. She paid little attention to people or to things happening in the room."

On the ninth day she thought she was going to die and was anointed by a priest. She insisted that she still had influenza and said that she had been accursed and told people not to come near her on that account. She slept little or none. At 3 a. $\mathrm{m}$. on the tenth day she became violent, disordered her room and hurled objects at any one entering. She finally quieted down, but became excited and disturbed again the following day. Then she was seen by a reliable physician, who examined her carefully and concluded that, in spite of very active reflexes, she did not have meningitis which he had suspected because of an apparent stiffness of the neck. She was deaf for one day. She continued to show major and minor conduct disorder, but without any loss of memory or orientation, and without hallucinations, suicidal threats or homicidal ideas. Delusions were very vague. She would make such incoherent remarks as, "I have picked out a rat hole," and "I am a slacker and I am not going to die." She was sent to this hospital on the eleventh day.

Mental Examination.--The patient was never fully accessible. For the first few days she answered questions, but with varying degrees of relevancy. Sometimes she would make sensible and accurate replies to question, but at other times she would refuse to answer or would reply with irrelevance, nonsense or inadequacy. After the first few days she became almost completely inaccessible. She mumbled frequently to herself about being cursed, going to hell, etc. She whispered to herself, attitudinized, gesticulated dumbly, answered hallucinatory voices, occasionally jumped impulsively from her bed and walked to one corner of the room, and returned to bed without a word, repeating the process for each corner of the room. She admitted hallucinations of God's voice, and those of various persons.

Subsequently, she lay almost motionless in bed, completely inaccessible, almost completely mute. Her face wore at times a pained, worried expression, but in general it was masklike and utterly expressionless. She showed negativism, catalepsy, and on a few occasions a transient flexibilitas cerea. She occasionally answered questions to the extent of complaining that her mind was being influenced, that people will not let her talk, that she was dead, etc.

One or two days during the second month she would answer a few questions relevantly and correctly, but with an utter indifference and with a far-away stare and absorbed manner which is difficult to describe, but which is perfectly familiar to any one with psychiatric experience.

At the present moment, three months from date of admission, she remains precisely the same. Occasionally she bursts into a mumbled jargon of incoherences accompanied by a silly, meaningless smile; at other times she renders a loud, wild shriek or moan without any apparent cause whatever. But in the main she lies stolidly in bed, making no motion, speaking no word. Catheterization and tube feeding have occasionally been necessary. 
Physical examination and laboratory findings were negative.

Diagnosis.-Catatonic schizophrenia (dementia praecox).

Another case further illustrating the same paradigm, but in the male sex, follows in abridged form.

CASE J.-Predisposition (seclusive temperament) + Infueña $=$ Schizo-
phrenia.

Family History.-The patient was a soldier, aged 27, single, and gave a negative family history.

Past History.-He was born in Vermont in 1891. His past history is not important. In temperament and disposition he is described by his brother as having been always of a quiet, seclusive disposition, never mixing with others, but preferring to remain alone. He was considered normal mentally by his employers, friends, and family, and he was not regarded as eccentric.

Present Illness.-He developed influenza and pneumonia at Camp Devens where he was a private in the infantry. He was delirious and did not regain his mental faculties. He knew his mother and father except on their last visit to him, at which time he had evidently recovered from everything except a mental disorder. His brother saw him two weeks ago and was recognized by him then. An interested friend writes: "I am informed that when he took sick he was out doing trench work, was missed at roll-call, but was not found until next morning, lying in the trench where he had been working after having lain out all night in a cold rain."

The military authorities sent only the information that subsequent to the influenza "he has been in a catatonic stupor; eats little; unclean in his habits; absolutely mute and unresponsive to external stimuli." He had been in the psychopathic ward of the base hospital for two months.

Mental Examination.-He was never accessible. He lay passively and apathetically in bed, responding to no questions by look or word. He obeyed simple orders, however, and cooperated in a fair way in the neurological examination. He made very mildly resistive maneuvers at times. After the first few days he was up and about the ward and was seen to look through magazines. He continued to show hypobulia and complete apathy. When offered a hand, he presented his own, and shook hands listlessly. He could not be urged, persuaded or forced to speak, smile, laugh, or cry. His facial expression remained fixed and impassive and his thought processes showed complete blocking. He seemed at no time unaware of his environment; his reception of external stimuli was not interfered with. Thus, when told to indicate by signs nis interpretation of some object, he did so slowly and disinterestedly, but quite correctly.

Physical Examination.-This was negative, as also the laboratory findings, including spinal fluid, and Wassermann tests were entirely negative.

CASE K.-Normality (!) + Influenza = Schizophrenia.

Family History.-A single woman, aged 20, was a bookkeeper by occupation and was born in Massachusetts. Her grandparents' history was negative. Parents: Father, 42, salesman; temperate user of alcohol; well. Mother, 41, always strong and well. Although described as being of a nervous temperament she was cheerful and not seclusive or sensitive. She had a premature menopause at 28 , at which time she had "hysterical attacks." In these attacks she became excited, exhibited mild conduct disorder, and sometimes fell to the floor 
with flushed face and some frothing, "but never lost consciousness, bit her tongue, injured herself" or passed urine or feces. Since the abatement of attacks she has grown entirely strong and much less "nervous" and "now has good self-control," and a cheerful, even temperament.

Past History.-The patient was born in Chelsea, in 1898; normal but somewhat difficult delivery. She was developed normally, physically and mentally. Puberty occurred at 13 years; no disturbances. Education: She started to school at 5, quit at 16, two years of high school, one double promotion at 11 or 12. Never held back. Did well; mathematics difficult. Very quick in languages. Never held back or kept out. Economic: From 16 to 18 she was home with her mother. At 18 , she became a bookkeeper at $\$ 12$ a week. Has worked steadily with little vacation for the same people; eight-hour day but little responsibility until last three months. No court record or marital history.

Personality.-Lively, talkative, systematic, practical, level headed, social "but does not care particularly for social functions"; sympathetic, generous, sociable at home and domestic. Goes to theater with her mother. Plays piano. Has many friends. Pleasant, even disposition. Not easily influenced." (Given by father and mother who seemed to be intelligent and honest informants.) Religion: Protestant, little interest. Habits: No alcohol. Meals, wholesome and regular. Does not care for men. Thrifty, and a good housekeeper. Medical: Whooping cough at 6 months. At 1 year, measles (slight). At 18 months, tonsillitis. Has never been ill or had a physician since. No nervous attacks.

Present Illness.-"Patient is very ambitious and since the head of her department went into the army in June, she has had great responsibility. Has had charge of payroll of 150 people, directed the bookkeeping and practically the entire office. Worked very hard and loved it."

September 28 patient went to bed with influenza. She was febrile for ten days, but not delirious. On the twelfth day a neighbor who is described as being a "religious fanatic" called on the patient and the parents ascribe to this interview a psychogenetic influence which it probably does not deserve. However, that evening the patient was very depressed, wept, and said she knew she was going to die. As a matter of fact she was much better. Three days later the family moved, although the patient was still bedridden. She continued to improve. However, four days later (nineteen days after the onset of the influenza) she became mute.

"She has not said a word to her father since then, although she had what seemed to be normal periods. Her mother said that she appeared more herself in the morning when she had had a good night than later in the day when she had grown tired. A menstrual period due on the nineteenth was missed for the first time in her life. She grew steadily worse; more quiet, apathetic, and showing minor conduct disorders. On five occasions she wanted to undress at improper times and places. Twice without apparent reason she went out in her nightdress. Occasionally she emitted bursts of laughter or weeping without adequate cause." She was brought to the hospital on November 6, still completely mute.

Mental Examination.-A fair, comely girl, rather slight, though well nourished with a face of intelligence and culture, but entirely devoid of expression. She practically never spoke. All queries were met only with a Mona Lisa smile, and no indication that they were heard. Once after persistent questioning she showed some annoyance and ejaculated, "Damn!" at one other time she said two or three incoherent words. Occasionally smiled. Otherwise there was no 
response whatever at any time. A nurse's note has it that she occasionally spoke to them and that she sang a few times while in the continuous baths.

Motor Status.-She was quite resistive to any examination, and gynecological was impossible. She ate and slept fairly well, but showed a distant aboulia, sitting about quietly without any show of interest. Frequently she would suddenly jump from her chair, run toward one of the physicians on the ward, and just before reaching him stop short, giggle in a wild and strange manner, and walk quickly back to her seat.

Emotional Tone.-She showed complete apathy. Occasionally there was some irritability; generally she wore a pleased expression and in a few days she seemed to be mildly interested in her environment, but in general she was quite indifferent.

- Physical Examination.-This was entirely negative except for hyperactive knee jerks.

Laboratory Findings.-These were entirely negative, including spinal fluid and Wassermann.

Diagnosis.-She was committed after two weeks with a diagnosis of schizophrenia.

\section{Group 9.-Cyclothymoses. Manic-depressive psychoses}

Gowers' dictum on the frequency of "melancholia" and the rarity of "mania" after influenza has already been mentioned, and as it is a representative conclusion of the psychiatrists who wrote concerning the 1890 epidemic, no others will be quoted here. It is an amusing commentary on the older diagnoses, that in a recent examination of the records of a state hospital for the years succeeding 1890, the diagnosis "melancholia" was almost universal on all cases suspected of having had grippe. This in spite of quite good clinical descriptions which clearly made out cases to be schizophrenic, maniacal, delirious, etc. I have previously pointed out ${ }^{24}$ that in psychiatric subjects depression is distinctly one of the less common symptoms. Manic-depressive psychosis appears, however, in episodes usually of the manic form, with considerable frequency in our series, in contradistinction to the reports of Gowers and others, and possibly due to more than mere differences in nomenclature and nosology.

Under this group three cases are here reported. In the cyclothymoses (or as I would prefer to denote them, the cyclopsychoses) there are, as with the preceding group, the individuals who have manifested a cyclothymic tendency either by attacks or by disposition, and those in whom no such history appeared. On this basis the cases given below were selected, to illustrate

CASE L.-Cyclothymic psychosis, manic phase, previous attack.

CASE M.-Cyclothymic psychosis, manic phase, no previous attack.

CASE N. - Cyclothymic psychosis, depressed phase, no previous attack. 
(An instance of the occurrence of the depressed phase in second or third attacks could be added, but the analogy to Case $\mathrm{L}$ is so obvious that it is omitted to save space. Only a few such occurred.)

CAse L.-Cyclothymic Tendency (Previous attack of psychotic depression) + Infuenza $=$ Hypomania (Cyclothymic psychosis, manic phase).

Family History.-The patient was a man, aged 22, Jew, born in the United States of Russian parents. His paternal grandparents both died of pneumonia; maternal grandparents "of old age." Paternal uncles living, three; dead by trauma, one. Maternal side : one uncle insane, "was quiet and would not speak," died at a Massachusetts state hospital at 38 after three years' residence. Father, aged 50, living and well. Mother, aged 45, said to have diabetes.

Only the one instance of mental disease in the family history.

Past History.-Born in Massachusetts; negative history of birth, infancy and childhood, except for enuresis until 14 years old. Attended school from 4 to 20, taking part of the high school work, including the commercial course. Was obliged to repeat the first, second and sixth grades. Deportment always good.

Occupation.-Left high school to go to work as a clerk in his father's store. Joined the army August, 1918.

Mcdical.-Diphtheria and smallpox in youth. Gonorrheal infection at 20 . Herniotomy a short time prior to this.

Habits.-Total abstainer from alcohol. Masturbation from 6 to 12, and sexual promiscuity from 7 till the present time. "Cabarets and vaudeville have been his chief forms of amusement."

Disposition.-Very happy, sunny, constantly active, with a fondness for work and disinclination for reading and religion. Occasional spells of depression.

Previous Psychiotic Episode.-Two years previously he had had a distinct phase of depression lasting two months. He did not receive hospital care.

Present Illness.-While at Camp Devens, a private in the infantry, he contracted influenza of moderate severity and duration. During convalescence he first developed apparently a short depressed phase, succeeded by increased activity and elation which necessitated his transfer to Boston. (Details on military cases were never satisfactorily obtained.)

Mental Examination.- - He was an alert accessible, and loquacious young Jew of rather high empathic index; he talked very freely, with circumstantiality, frequent abrupt alterations of subject matter and manifestation of a crowd of ideas. No disturbance of orientation, memory, or thought content was demonstrated. He had a few fleeting phantasmagoric ideas which could carcely be called either delusions or hallucinations; e. g., he said it "seemed as if all the girls with whom he had ever had sexual relations were in the palm of his hand." Gross conduct disorder was never observed; he was rather hyperactive, but easily controlled, and highly appreciative of efforts in his behalf, such as the prolonged baths, which he enjoyed immensely. Emotionally, there was a typical elation of mill degree.

Psychologic test rating: mental age, 16.

Physical Examination. - Well developed and well nourished; hyperactive refiexes, pseudoclonuses of ankles. Blood pressure: systolic 120, diastolic 70 . Otherwise entirely negative. 
Laboratory Findings.-Urine, blood cytology and serology, and spinal fluid examination complete, all negative.

Diagnosis.-Hypomania.

CASE M.-Normality (?) + Infuenza = Cyclothymic Psychosis, Manic Phase.

Family History.-A boy, aged 17, was a student and was born in Massachusetts. His family history was negative in all respects, including his grandparents. There were four siblings, all living and well, and no miscarriages.

Past History.-This was carefully obtained in the outpatient department of this hospital when the patient was about 12 . It was in all respects entirely negative. His birth, infancy and childhood were entirely normal. He talked at 8 months, walked at a year, attended kindergarten, grade, and high schools and did good work. He was studious but not seclusive and evidently had a rather superior personality. He was athletic and interested in tennis, swimming, etc.

From the age of 7 until the age of 13 he was troubled by stammering. $\mathrm{He}$ attended a class for speech impediment in the outpatient department of this hospital, and was very much improved after a year or so that he discontinued his attendance. Except for this his medical and mental past history is entirely negative.

Present Illness.-He was working hard at various school activities in a boys' academy, having many duties in addition to his curricular work. Besides a scholarship, he had earned some $\$ 300$ at outside activities, and had kept in excellent health until October 1 . At that date he contracted influenza and was very ill, running a temperature of $105.5 \mathrm{~F}$. for three days. He was able to be out by the sixth day, but a cough and much restlessness continued. He played tennis, went automobiling and took a short vacation, but continued to show a distinct hyperlogia, making extensive plans for the immediate and distant future. On the twelfth day this became very noticeable. He "talked rapidly from one subject to another," spoke of being nervous and wondered if he wouldn't go crazy. He was given morphin by a private physician, but without apparently much effect. His hyperactivity continued, and he was brought to this hospital at 1 a. m., October 13.

Mental Examination.- "The patient is rather tall, slender, attractive youth of 17 who is hyperkinetic, talkative, and elated. He confers various military ranks on the physicians in the hospital, elects the nurses to the Red Cross service, and announces large salaries for the attendants, etc."

"I am absolutely perfect. Have a cigaret? Here are two strings which they gave me for a test. Hello there, Major. We are all going to be in uniform before night. How old are you? I am 17 years and 9 months today and in 3 months I will receive a commission. . . . Girls? Yes, girls by the thousand. Girls from Wellesley, girls from Dartmouth . . . no, there are no girls from Dartmouth . . . girls from Smith, girls, girls. We'll put this thing across, and have all those beds put in. Can you see it? Will you help it? Never mind, not necessary." (Whistles!)

The patient showed hyperlogia and hyperactivity as were indicated from the day of admission until discharge on the tenth day. He amused himself and his audience greatly, performing antics unnumbered, and of infinite variety, particularly when in the prolonged baths, and particularly when observed. Emotional tone was that of elation, exaltation, euphoria. His thought processes showed typical flight of ideas, with distractibility, play on words, etc. His associations were easily followed, however, for the most part. Delusions were 
fleeting, and of the expansive and grandiose type, never paranoid, somatic or referred. There were no hallucinations. The conduct was as described above; hyperkinesis over a wide range, but usually readily controlled. He was obedient and not destructive.

Diagnosis.-Cyclothymic psychosis, manic phase. Committed.

CASE N.-Normality (?) + Influenza $=$ Cyclothymic Psychosis, depressed phase.

Family History.-This patient was a man, aged 24 , single, a chauffeur by occupation and was born in Boston. His grandparents were all born in Ireland, and died there at well advanced ages. His father was born in Ireland, a citizen of United States, a freight-handler, aged 51, without abnormalities of mental life. His mother was born in Ireland, aged 48, a charwoman, quite healthy. Possibly both mother and father are at least mildly alcoholic. Siblings: of parents, no social or mental pathology. Of patient, 8,3 dying in infancy of enteric diseases, the others living and well. No history of mental pathology anywhere in the family. Excessive alcoholism also denied.

Past History.-The patient was born in Boston in 1894, and according to the history furnished by mother was evidently a normal infant and child. $\mathrm{He}$ left school at the seventh grade to work, was 14 and was considered a good student; had not been held back.

His economic history is rather varied, but not important. For some years he had worked as chauffeur, earning from $\$ 20$ to $\$ 25$ weekly.

Personality.--"He has a happy, sociable disposition. Has been very good to his mother, giving her most of his wages. Is fond of motion pictures, Chinatown suppers, and social parties. Is much liked, and is not suspicious." Catholic. Habits: Occasionally drank beer; "never seen or suspected of being drunk." Medical: Scarlet fever at 4 , very severe and protracted. Diphtheria at 7. Since then never sick, until present illness.

Present Illness.-Ten weeks prior to admission he is said to have had influenza. "He was very ill. Temperature could not be taken because his teeth chattered so. He was in bed 7 or 8 days. He had night sweats (thereafter) for about a week."

He returned to work after two weeks, "but looked pale and weak but felt pretty well." He remained at work a week and "had a relapse." "He had a chill, sweats," and probably fever. He was confined this time for nine days, but was not in bed throughout this time.

Thereafter he felt quite incapable of returning to work. He "thought that he was dying," that "some one had given him the disease a second time," that "he couldn't seem to take hold and do his work." This continued for two weeks.

Two days before admission he called to his mother, asking what it was that was in bed with him, that it had frightened him. He was not suicidal, however, nor did he show conduct disorder nor react more definitely to hallucinations.

Mental Examination (abridged).- - He wore constantly a pained, doleful, anxious expression. He was accessible, and tried to cooperate, but was not very successful because of his aboulia, retardation, and a suggestion of impoverished, intellectual processes. Orientation precise in all spheres. Memory general, rather faulty, perhaps due in part to abstraction. No hallucinations. $\mathrm{He}$ had an imperfectly formulated delusion that he had recently contracted venereal disease. No others. There was partial insight. . . . "Sometimes I don't seem right." His thought processes showed a conspicuous retardation, with 
rather weak associations and an attention difficult to secure or retain. His motor status was distinctly that of hypokinesis and abulia. $\mathrm{He}$ sat about the wards all day, with head hung, and without demonstrating interest in anything. When obliged to move he did so with slow, irresolute movements, and with an air of lugubrious torpor. His emotional tone was incontrovertibly that of depression. He was "blue," "lonely," "worried," "down-hearted." $\mathrm{He}$ was never seen to weep, or to smile; he commented once that "some days things seem dark, and other days brighter."

Physical Examination.-This was entirely negative except for exaggerated reflexes and a tremor of the hands.

Laboratory Examinations.-These were negative, including spinal fluid and blood Wassermann tests.

Results. - His condition remained unchanged. He was removed against advice on the ninth day.

Diagnosis.-Depressed phase of cyclothymic psychosis (manic depressive, depressed).

\section{Group 10.-Psychoneuroses}

There is a book (4 vo) written in 1890, and now little read, entitled "De l'hystérie consécutive à la grippe" (Le Joubioux ${ }^{43}$ ). The phenomenon referred to is striking and frequent enough to have attracted attention after each of the later epidemics of influenza. Grasset, Krannhals, van Deventer, Worms, Josserand, Huchard and many others have contributed reports and discussions, the consensus of which is well put by Leichtenstern. ${ }^{16}$ "Hysteria and neurasthenia not infrequently arise from influenza or are enormously exaggerated by it. All forms of hysteria have been observed. . ."

He then asks the important question, "Is a neuropathic predisposition the basis of hysteria and neurasthenia when following influenza?" and answers "probably . . . in the affirmative, in most cases. On the other hand . . . severe postinfluenzal hysteria has frequently been observed . . . (where) no hereditary or acquired neuropathic tendency could be found." In this he simply speaks for a number of observers, some of which he quotes.

To circumvent the question, I present herewith two cases, one having a definitely manifested predisposition to psychoneurotic episodes, the other quite without any such tendency.

CASE O.-Psychoneurotic Tendency (manifested by a previous "hysterical attack") + Influenza = Psychasthenia.

Family History.-The patient was a woman, aged 34, born in Cambridge. Her paternal grandparents were Irish, both lived to be over 90 ; always healthy and temperate. Her maternal grandparents were Irish and English; both died "of old age" in the eighties; also healthy and temperate. Her father was born in Ireland, and came to United States when 12 years old. He died at 71 of

43. Le Joubioux: Thèse de Paris, 1890. 
"cancer of the intestines." He was a railroad night-watchman, temperate and healthy. Her mother was born in Ireland and is living and well, aged 73 . Paternal siblings, 9; maternal siblings, 8; all are living and well. There had been one miscarriage, at 6 months, during typhoid fever.

Past History.-The patient was born in Cambridge, Oct. 29, 1884. It was a normal delivery, a healthy baby, and she passed through a normal childhood. Puberty occurred at 14 or 15 without disturbance or illness.

Education: She entered the kindergarten at 3. Went through grade schools and finished the second year of high school at age of 15. Considered "very bright" and had "double promotion" twice.

Economic history: On leaving school worked two years as a night telephone operator. Mother objected, and so she remained at home for a year or more. From 21 to 30 she was employed as a saleslady by one firm, at $\$ 10$ a week. Has not worked steadily since (vide infra).

Not married. No court record. Habits normal. Religion: Catholic, devoutly held. Medical history negative except for the surgical removal of a small cyst and the appendix in July, 1917.

Personality described as "sympathetic, very sensitive, but not suspicious or jealous. Unselfish, very sociable, never irritable or critical. Fond of music and singing. (The mother, who gave the account, adds that "for a year I have not let her play because it seems to make her nervous.") It is thought that she was influenced rather with difficulty.

Previous Episodes.-The patient is well known to the outpatient department of this hospital. Four years previously she suddenly became "hysterical" at the sight of a brother dying with tuberculosis. She failed to recognize him [sic], cried "uncontrollably," and remained depressed and lugubrious. Her own account is identical, in that she explains that she was so "shocked" by her brother's appearance and so appalled at her helplessness in the situation that she had "an hysterical collapse" and was led from the room "screaming and crying." She was not able to work thereafter with any degree of proficiency. Although better at times, and particularly when under the surveillance of the social service department, she was nevertheless prone to "attacks" of profound despondency and weeping, once a month or less frequently. The social service worker finally established her at knitting on a commercial basis in her own home and she was diligent and efficient thus employed, knitting over fifty sweaters in the past year, and coincidently feeling better than previously. She was consistently and persistently followed by the outpatient department and a voluminous literature has accumulated in her folder. The diagnosis there made was psychasthenia. She was considered much improved and had not been seen for nearly a year by the physicians.

Present Illness.-On October 10 she contracted influenza. "She had a temperature of 102 and $103 \mathrm{~F}$. for the first few days. The fever did not pass for ten days; she was in bed about three weeks. For about two days, at the beginning, she was out of her head." Thereafter she seemed much the same for three weeks. On November 21 she complained of severe headache "and mumbled things to hersolf. She seemed much distressed and a fraid of going crazy." She was brought on the following day to this hospital.

Mental Examination.-A young woman of rather large frame, well nourished, attentive, accessible, and cooperative, but very much self-centered. Consciousness entirely clear at all times, speech normal, orientation precise, memory free from defect. She gave a rather more detailed account of her past than that 
furnished by the outside informant, but the main facts coincided throughout. She denied any stigmata of masked epilepsy (enuresis, somnambulism, etc.). Obsessive, obscene thoughts began to trouble her shortly after the attack of four years ago. She said they did not seem to originate from any particular cause of experience and they persisted for a year and a half. After the consultations in the outpatient department this improved and she was comparatively free from these thoughts.

Her account of her present illness is as follows: For some time she has been fairly comfortable mentally and physically and busily engaged in knitting sweaters at home, proceeds from the sale of which afforded her some little income. After a prolonged attack of influenza she began again to be troubled by obscene thoughts "much more than ever before." She told no one about them for two weeks, but they became so distressing that she could endure it no longer and following an expression of her feelings she was brought to this hospital. These thoughts are obscene and sexual suggestions and phantasies which "possess her whenever she is approached by any person." They come in spite of her dislike for them and her avowed efforts to keep them from her mind. They seem to have no particular reference to certain types of persons, they were not accompanied by hallucinations. "Something seems to grip my brain." After the thought comes the regret and chagrin that she should have been guilty of such thoughts. They seem to come in distinct showers; thus "today had none until about 3 p. m., when on roof garden" and "frequently has them after retiring at night." Latterly the obscenities became related to religious matters, but she was unable to explain this adequately.

In addition she had some symptoms of the "folie de doute?" Thus for example she said "Sometimes I seemed compelled to repeat sentences, things I hear. If some one says breakfast is ready I feel as if I must keep repeating to myself, "breakfast is ready, breakfast is ready."

She was precisely oriented, showed no memory defect, no hallucinations or illusions, no delusions, good insight and judgment, a rather variable emotional tone swinging from depression when introspective to pleasant, cheerfulness when distracted, normal thought processes and motor status. She was distinctly suggestible and was considerably improved by unsystematic suggestive therapeutics.

Physical Examination.-This proved to be essentially normal in all respects. Reflexes were slightly hyperactive; blood pressure was systolic 140, diastolic 80 .

Laboratory Findings.-These were negative as to urine, blood serum, spinal fluid and vaginal smear.

The patient was discharged considerably improved after two weeks, with the diagnosis of psychasthenia.

CASE P.-Normality + Influenza $=$ Hysteria.

Family History.-A girl, aged 15, was a student, and was born in Massachusetts. Her father was living and well, aged 52, not alcoholic. Her mother, aged 49, was always very healthy except for a gradual increasing deafness for the past fifteen years. "She has always been rather nervous and high strung and recently more irritable than usual." The patient stated that the entire family were "rather nervous and easily excited," but there was no history of nervous, mental, or epileptic disease in the family. One sister, aged 18, is healthy. Two siblings died in infancy of unknown causes.

Past History.-The patient was born in a suburb of Boston in 1903. She was rather weak and "sickly" until the age of 5 , but since that age had enjoyed 
unusually good health. Aside from the usual diseases of childhood and ar occasional "cold" she had never been ill. There was no history of convulsions or other stigmata of epilepsy.

Educational: She started going to school at the age of 6 and was at the time of examination in the third year of high school. School work was always done very well and with genuine interest. Although she found her studies easy . she was rather too asiduous and studied late into the night.

Personality: She seems to have been always a cheerful, happy individual with many friends and with one particular chum with whom she had associated closely for three years. Although her interests seemed to be confined chiefly to her school work she was definitely social, enjoying a crowd and disliking very much to be alone.

Present Illness. - The patient herself gives a very good account of her present illness, and it is here reproduced with minor modifications. An attack of influenza began November 2. She was in bed for about a week. She had a temperature as high as $103 \mathrm{~F}$. There was apparently a good recovery after this, but about two weeks ago, since she started back to school, she noticed that she tired very easily, and felt she was overworking. She admitted that she had been studying more than usual in order to make up for the time she had missed.

The day before coming to the hospital she felt particularly tired. She had been studying late the night before, preparing for an examination, and felt so tired the next morning that she did not eat any breakfast, and also missed her lunch while at school. That afternoon she went to her friend's house, and while there became even more worn out. She said she did nothing out of the ordinary that afternoon, but after she had been there awhile she became rather silly. She felt that she was rather excited, and would laugh without provocation, and would say foolish things. Soon, however, she quieted down, and while sitting and talking realized suddenly that her left leg felt as if it had gone to sleep. She could not feel anything at all - felt as if it were gone. Tried to stand up but it collapsed under her, and she saved herself from falling by grasping a chair. This frightened her and she thought that perhaps she was going to be paralyzed. Then the other leg began to feel the same way, but not so markedly. The doctor was called soon after this, and he said it was nothing but nerves, and that she would be all right. This comforted her and although she felt too weak to go to her home she spent a restful night at the house of her friend. The next morning she was feeling entirely all right except that her legs were sore, and she had a rather severe pain in her back. She endeavored to get dressed so that she could go to her own home, but the pain in her back and legs would increase on any attempt of movement. That afternoon she thinks she must have become delirious because there are periods concerning which she can remember nothing. She would come out of these confused periods, and have no complaint except the soreness in her back, but soon she would drift away into unconsciousness. Once or twice while she was unconscious she felt that she was blind. She could see nothing, but would talk to the people around her and ask them why the room was so dark. They told her afterward that the light was on and that they could see perfectly clearly. These periods of blindness lasted only a few minutes. She knows nothing about what she said or did during the periods when delirious, although since she has been told about it by her family. She was afraid this time that they were going to take her away, send her to some hospital, and she would not be able to see her friends. She thinks she probably talked about this during the delirious periods. 
She still was rather confused and uncertain when she came to this hospital, but the following morning felt entirely normal and has been that way ever since. She tells also of "an occasional lump in her throat, causing her to nearly choke." When asked about her girl friend, she admitted that she cared for her very much, but denied anything of a homosexual nature in their relations. Nothing of this kind could be elicited in any way. She admitted she had done a great deal to further the match between her friend and her cousin who is in France. She even wrote letters to her friend and signed them with the name of the man who is in France, but said she told her friend about it a month or so afterward. There had been no deception for at least three months on her part. She did not know whether the girl had been deceiving her or not.

Mental Examination.-Orientation precise, memory absolutely unimpaired except for certain recent events as detailed above. No delusions, no hallucinations, good insight. Thought processes show excellent attention, quick and coherent associations, normal train of thought, speech free from fault. Emotionally cheerful and pleasant. Conduct above reproach.

Physical Examination.-Entirely negative in every respect. The same is true of the laboratory examinations which included spinal fluid, blood serum, urine and vaginal smear.

Psychologic Examination.-The patient graded regularly at the mental age of 18 plus. Her performance on the construction puzzles was fairly good and on the memory tests good. In the suggestibility tests she accepted ten of ten suggestions. Patient cooperated well.

She showed no further evidences of mental disease during her stay here. She gave the impression of being "high strung" and "of an hysterical type" to various physicians who examined her. She was discharged improved after five days, with a diagnosis of hysteria.

Group 11.-Psychopathoses. Psychopathies, and the unclassified

It was Southard's intention that in this group there be included not only those cases of dubious mental pathology who are variously classified as "constitutionally inferior," "psychopathic personality," "defective delinquent," etc., but also those occasional instances of psychotic forms entirely aberrant from any recognized type or group. These cases in which there is no possibility of agreement on a comprehensive and justifiable diagnosis of any kind are relatively infrequent, but they are common enough to be well known in private practice as well as in institutional work.

The following instance is perhaps not the best example, but it serves in a measure because of the strong suggestion of psychopathy and because of the precipitation of symptoms by influenza, although the influence of the latter is equivocal. I am aware of the similarity in some respects of this case to those described by Grasset, ${ }^{44}$ Krannhals, and in the German army reports, as mentioned by Leichtenstern ${ }^{16}$ and epitomized as "the so-called hystero-epileptic [sic] attacks, occasionally

44. Grasset: Leçons sur la grippe, Paris, Masson et Cie; Montpellier, Coulet, 1890. 
associated with fits of crying." Nevertheless, I agree with the intimation therein put forth that the demonstration of the hysterical nature of those phenomena (even if this case be proved to be similar) is not wholly convincing.

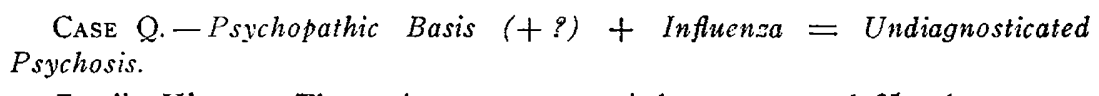

Family History.-The patient was a married woman, aged 35, whose occupation was housework; she was born in Nova Scotia. Her grandparents' history was negative except that "patient states that she heard her father say that his mother lost her mind after her son had been killed." Both parents were living. Her father was 60 , mother 66 , father well, mother crippled by "rheumatism." Siblings, four living and well, three died in childhood (scarlatina, drowning, and "unknown"). No history of mental disease in family.

Past History.-She was born in Nova Scotia in 1884; full term, normal delivery. She passed a normal childhood, except for somewhat inferior physical status. "She was always the delicate one of the family." Had measles and scarlatina ; later "chronic bronchitis." Was "always nervous."

Educational: There is some discrepancy in the accounts of her schooling. but at any rate she was a rather superior child and is said to have been in the eighth grade at the age of 13 . She left high school at the end of the first year to get married. Her school work seems to have been very good, and she was not held back.

Economic: She worked for about a year just prior to marriage, at a Boston department store. Other than this she never did anything but housework.

Marital: Married at 16 to a private detective who never properly supported her and who eventually deserted her when her youngest child was 5 weeks old. She later obtained a divorce. He alleged immorality on her part (while married to him), which she denies. There were three children, all living and well, aged 16, 14 and 11 . In addition there were several self-induced miscarriages.

Subsequent to her separation from her husband she was sexually intimate with two men, whose names she gives. These indiscretions had an important relation to her present illness.

Previous Nervous Trouble: Five years previously she was in the outpatient department, because of insomnia, worry over children who were in custody of divorced husband at that time, paresthesias of legs, tingling in hands, supposed loss of memory, inadequacy, etc. Given a few hydriatic treatments; improved.

Character: Not seclusive. Not muich adequate information secured because of prejudice of informants (including patient).

Present Illness.-Influenza began October 9. She was ill only two days. "Following this, however, she was unable to sleep and she could not think right. She has great difficulty in recalling what she did the next few days. Then she commenced worrying over her recent sex indiscretions. To add to her troubles a young niece died of influenza on the 12th."

She was brought to this hospital on the 18 th by her father. The admission note reads as follows:

"In admission office the patient at first refused to answer questions. Then said there was no reason for her coming here. Is afraid that she is going to be killed here. Does not show any marked emotion over it, however." Later in the ward, "she is pleasant and accessible, and does not appear apprehensive 
or depressed. No hallucinations or definite delusions. Says she had influenza following which she became depressed and retarded; now complains of feeling weak."

Mental Examination.-Orientation precise in all spheres. Memory intact except for events just preceding admission, which are apparently quite hazy. Ideation characterized by self-accusatory ideas; for example, she had disgraced her children by her sexual indiscretions; the nurses knew of her miscarriages from her chart and would look down on her; father and mother would find out about her, or be informed of what she had done. There was no insight, nor on the other hand any definite delusions. Hallucinations absent. Thought processes showed no irrelevancy, incoherency or retardation. Emotional Tone: Except for periods as described below, her emotional tone seemed to be quite normal; she was cheerful and pleasant and responded to interrogation freely and cooperatively. The attacks described were accompanied by wailing and followed by singing; it was impossible to determine what or how she felt emotionally.

Motor Status.-The characteristic feature in the case was the frequent outbursts of wailing, shrieking and weeping, accompanied by a clonic stiffening of the muscles of her entire body, and a flushing of the face. These attacks were of perhaps twenty minutes' duration; they were sometimes induced by interrogation on the matter of her indiscretions, but at other times she answered the same questions with no disturbance whatever. The manifestations differed slightly at different times, but the essential things were complete inaccessibility because of a lugubrious demonstration which was in some cases followed by equally inexplicable elation. At one time during an attack, when she was stiffened out tensely, a pinprick test was attempted and she was found to be anesthetic.

She herself explained these attacks on the basis that she "felt so degraded" to think she would be suspected of immorality. Yet this she freely admitted, and at the same time insisted that she was sexually frigid.

Still another type of conduct disorder appears in the following interrogation, which also gives a good idea of her type of response: (One night you did a great deal of screaming, and pounding on the door.) "No, it was morning."

(What time?) "It was after breakfast. I had spent an awfully restless night and I went in and asked Miss P. if I could lie down. She just took me and threw me into the cells there, and I got into a kind of frenzy."

(We have no cells here.) "I thought it was locked. She slammed the door so hard that I thought she locked it."

(Even if she had locked it?) "I got awfully frightened. I have a home and three children and I want to go home to them."

(Are you afraid to be left alone with yourself?) "No, I am perfectly safe alone."

(I don't see why you should be so frightened?) "Just a terror came over me."

Physical Examination.-General hyperalgesia. Positive Romberg. Reflexes normal, except knee jerks which, although equal, were diminished. Blood pressure, systolic 118, diastolic 62 .

Laboratory Findings. - Urine, blood serum Wassermann test, spinal fluid (including Wassermann test), vaginal smear and complement test for tuberculosis all negative.

Psychometric Test.-The patient graded regularly at a mental age of 18 . In the supplementary tests her performance in the construction puzzles was 
good. The memory tests were also well done. She showed fairly good comprehension and judgment in the apperception picture puzzle. She accepted two out of ten suggestions [sic]. She cooperated well.

She showed some improvement, but was committed.

The diagnoses made here ran the gamut of psychiatric possibilities, including dementia praecox, psychopathic personality, and psychoneurosis. Against the first named is preeminently the absence of schizophrenia. Against psychoneurosis there is less definite proof, but it might be pointed out that her conduct was much disturbed, that insight was completely lacking, that it was not proved that she was hypersuggestible or bore stigmata of hysteria at all, and finally that she was committed. The possibility of cyclothymic psychosis may be suggested, but the absence of any constant depression or elation, and the absence of retardation at all times, makes this rather unlikely.

\section{SUMMARY}

The effect of influenza on the brain may now be considered analytically by summarizing the cases collected and detailed in the foregoing.

There are obviously two methods of approach: One may consider in summary merely the end results, which being the matter of primary pragmatic value is usually considered first. Complementary to it, however, is the study of the component essentials, the basis and contributing factors which together bring about the final product, a study of the material on which the influenza acted to produce specific results.

Considering the first method, one may tabulate the paradigms to show the end results thus (in Southard's order):

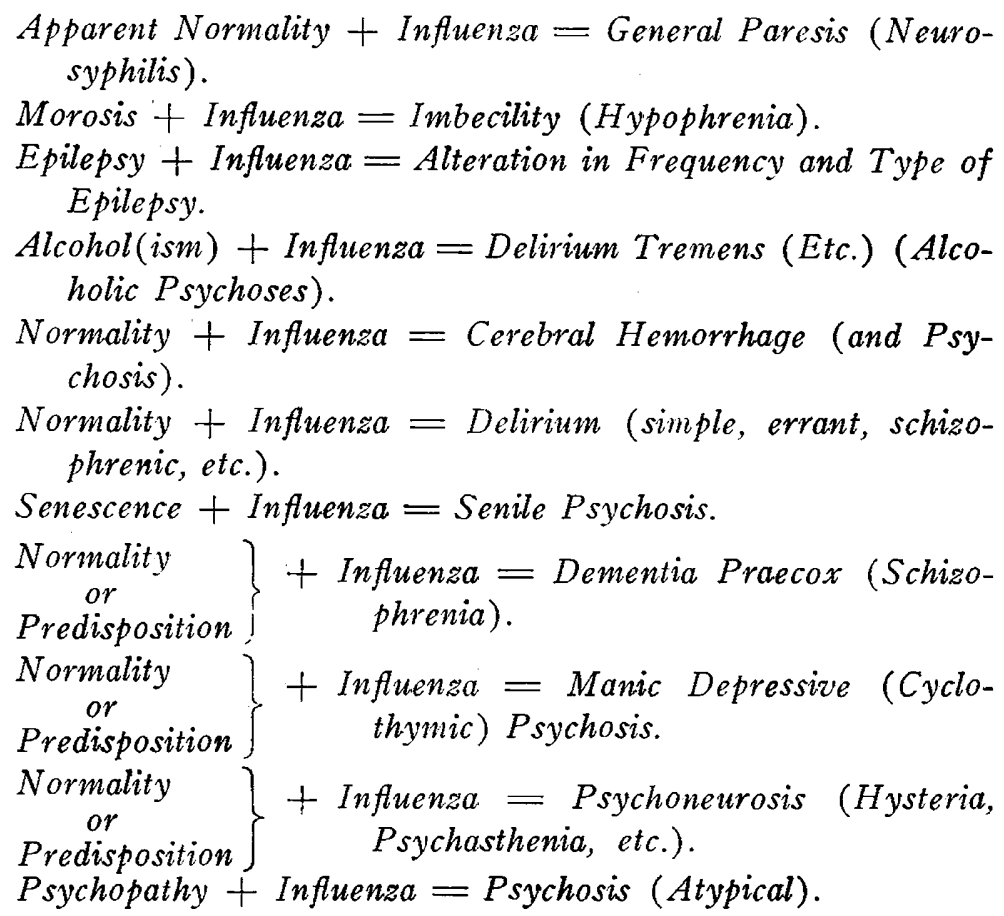


From this presentation one is justified in the conclusion that any form of mental disease may follow influenza. But this is to declare a chronologic relationship only, and to imply or assume an etiologic connection that only a study of the component elements of the equation can justify or elaborate.

In a sense, we should be justified in urging in place of the phrase "influenzal psychoses," which literally do not exist, the more cumbersome but more correct expression, "influenzal neurotoxic effect (or product)." Surely the most striking and noteworthy fact is the variety of psychic (and encephalopathic) lesions. This fact alone is particularly and specifically intolerant of a doctrine of specificity. This we may say without reference to the modifying or even determining factors contributive in each case or group of cases, simply because of the great inclusiveness of the list. A disease - an incident - which is capable of calling forth psychiatric pictures as widely different as general paresis and hysteria (I temporarily waive the point that in neither case cited as illustrating these phenomena was there any previous indication of mental trouble), and which does not fail to leave its conspicuous impression on every intervening group of mental disease in a representative list, can surely not longer be accused of possessing psychic specificity.

Reversing the point of emphasis, now, and considering minutely the left-hand side of the equation, the components of the sum, we may tabulate the cases in three groups. Primarily, there are those arising. on a basis of undisputed psychic normality. In these the left-hand side of the equation reads throughout:

$$
\text { Normality }+ \text { Influenza }=
$$

These are distinctly psychoses of creation, as opposed to psychoses of precipitation, revelation or alteration. I have suggested these terms as descriptive of the process involved merely as useful figures, and without presuming to indicate what psychopathologic process actually takes place. It is established that this is what seems to take place, and these then are the processes that seem to be represented. The first one, creation, is represented by the following paradigms:

Normality + Infiuenza $=$ Delirium.

Cerebral Hemorrhage with Psychosis.

Senile Psychosis (?)

Schizophrenia (Dementia Praecox). Cyclothymia (Manic-Depressive). Hysteria (Psychoneurosis).

The next groutp of equations are those in which the influenza acts on an avowedly predisposed soil, resulting in the production of a 
psychosis of a specific form, exactly analagous to those mentioned in which no evidence of predisposition was shown to exist. These cases are based on equations the left side of which is uniformly

\section{Predisposition + Influenza $=$}

They represent a process to which scores of verbs have been applied. The French and German terms are scarcely less numerous than the English, and "provoked," "incited," "instigated," "produced," "called forth," and "excited" are only a few of these. The inference is that the nature of the process is frankly not understood. If I prefer to use the term "precipitated," it is not with the idea that it expresses any better conception of the nature of what takes place. Elsewhere there will appear shortly a more presumptuous attempt to liken the process to that of catalysis in chemistry, but I do not urge this here. This group, representing the process, we will say, of precipitation, is represented by the following paradigms in the above cases:

$$
\begin{aligned}
\text { Predisposition }+ \text { Influenza }= & \text { Delirium Tremens (etc.). } \\
& \text { Schizophrenia. } \\
& \text { Cyclothymia. } \\
& \text { Psychoneurosis. }
\end{aligned}
$$

Finally, there is a smaller group representing the power of influenza to alter the nature or degree of a neuropathologic or psychopathologic lesion already extant. These cases may masquerade under guises sug.gestive of a process primarily of revelation, such as the revelation of a heart lesion by an attack of pneumonia. Thus the appearance of general paresis immediately after influenza might simulate this, but actually it probably amounts to but an augmentation or hastening of a process no doubt already established, and possibly capable of detection were all the refinements of diagnosis possible of application in an unsuspected subject. This group, representing the power of influenza in the alteration of pathologic brain processes, is represented here by

Morosis + Influenza $=$ Imbecility.

Epilepsy + Infuenza $=$ Alterations in frequency and type.

Psychopathy + Influenza $=$ Psychosis.

Apparent Normality (Latent Neurosyphilis) + Infuenza $=$

General Paresis.

(Mild Neurosyphilis + Infuenza = Advanced Neurosyphilis).

Influenza thus acts apparently in a nonspecific manner to do specific things; to create psychoses, to precipitate them in predisposed persons, and to augment or alter them where already existent. So powerful and so versatile a neurotoxin is certainly not possessed by any other acute infection. It is conceivable, although scarcely so, that were there 
some other potent infecton as ubiquitous as influenza, its neuropsychiatric effects might be as numerous and as various, but certainly evidence does not favor this. It is not true of the sequelae of the great plagues of typhoid and bubonic plague that once raged; lobar pneumonia is certainly common enough and widespread enough to have resulted by this time in a similar host of nervous sequelae were it akin to influenza in neurotoxic effect. Quantitative specificity, in point of high potentiality in neurotoxic effect, is apparently fairly claimed by influenza.

Finally, the writer would add a word in defense of the equation paradigms as used in this article. I am well aware, of course, that it is impossible to accurately and wholly express any biologic process in chemical or mathematical formulas. They have been adopted here, not for expressing the whole truth, even if anyone grant that to be attainable, but the essential truth as concerned with influenza, the human basis on which it works and the psychosis which succeeds. There are doubtless many elements entering into the formulas expressing influenzal action on human brain which are not represented in the paradigms of this article, elements which while absolutely indispensable to the complete configuration of the process, are in no way essential to the basic principles represented by the simpler and wholly pragmatic cryptograms.

\section{CONCLUSIONS}

1. This paper aims to illustrate the forms of psychoses associated with influenza by the presentation of representative cases.

2. The history of the study of the association of mental disorder and influenza is traced roughly from its inception in 1385 to its frank recognition in 1790 and its elaboration since then.

3. Southard's Eleven-Group nosology is commended by its mechanical convenience and its neat inclusiveness, and serves admirably to present cases illustrative of findings as follows:

4. Active neurosyphilis (Southard's Group 1) may be precipitated by influenza (and cases of sluggish course accelerated). (Case A.)

5. Hypophrenia (Group 2) may be augmented in degree, and a case of the apparent process "Morosis + influenza $=$ Imbecility" is cited, but no evidence was obtained for the production of total loss of intellect, the acute dementia of the iodiocy type, or Kraepelin's misnamed "infectious idiocy." (Case B.)

6. Epilepsy (Group 3) may be altered quantitatively and qualitatively, that is, in the frequency and in the form of attacks, but there were no instances of its initiation by influenza in our series. (Cases C and D.) 
7. Delirium tremens and other forms of alcoholic psychoses (Group 4) were quite frequently induced by the added toxemia of influenza, but probably in no greater frequency than would obtain in a similarly large number of any acute infectious disease. (Case E.)

8. Of the encephalopathic psychoses (Group 5) the occurrence of Leichtenstern's influenzal "hemorrhagic encephalitis" with a peculiar psychosis was demonstrated clinically and by necropsy. (Case F.)

9. Delirium (Group 6) remains the most polychromatic and versatile of mental disease pictures; its association with influenza is notoriously frequent, and its manifestations bewilderingly multiform. It stands as the type illustration of the paradigm, "Unknown factor + influenza = psychosis." (Case G.)

10. Of psychoses associated with senility and the presenium (Group 7) one rather equivocal case is presented as having been initiated by influenza without previous indications. (Case H.)

11. Schizophrenia (Group 8), cyclothymic psychosis (Group 9) and psychoneurosis (Group 10) occur following influenza with and without predisposition or previous manifestations. Instances of all are given in detail (Cases I, J, K, L, M, N, O and P.)

12. Undiagnosticated psychoses and psychopathias (Group 11) form rather too vague a group to be considered categorically, but a representative case is given in which influenza incited a psychotic episode in a (?) psychopath. (Case Q.)

13. The cases presented may be summarized by paradigms, exemplifying the psychiatric effects of influenza, viz.:

(a) In the process of Creation:

$\begin{aligned} \text { Normality }+ \text { Infuenza }= & \text { Delirium (simple, errant, schizo- } \\ & \text { phrenic) } \\ & \text { Apoplexy, Atypical Psychosis. } \\ & \text { Senile Psychosis (?) } \\ & \text { Schizophrenia. } \\ & \text { Cyclothymia. } \\ & \text { Hysteria. }\end{aligned}$

(b) In the process of Precipitation:

Predisposition + Influenza $=$ Delirium Tremens (etc.). Schizophrenia.

Cyclothymia.

Psychoneurosis.

(c) In the process of Alteration:

Morosis + Influenza $=$ Imbecility.

Epilepsy + Influenza $=$ Alterations in frequency and type.

Psychopathy + Influenza $=$ Psychosis. 
Apparent Normality (latent neurosyphilis) + Influenza $=$ General Paresis.

(Mild Neurosyphilis + Influenza $=$ Advanced Neurosyphilis).*

14. Influenza apparently acts on the brain in three ways: to create psychoses, to precipitate psychoses in predisposed subjects, and to augment or alter their form where already existent.

15. Thus we cannot from the present data regard influenza as capable of qualitative psychic specificity.

16. The quantitative specificity, however, of the influenza neurotoxin is confirmed by its remarkable potency and versatility; the large number and wide variety of psychic and encephalopathic lesions produced being one of the most striking neuropsychiatric features of the epidemic.

17. The question of predisposition is simultaneously answered, there being evidence to show that psychoses sometimes occur directly after influenza with no forerunning symptoms or signs, and sometimes occur then only atter months or years of less pronounced manifestations.

\footnotetext{
* Mentioned but not detailed in this article.
} 